\title{
The nuclear vitamin D receptor: Biological and molecular regulatory properties revealed
}

Haussler, MR., Whitfield, GK., Haussler, CA., Hsieh, JC., Thompson, P., Selznick, SH., Dominguez, CE., \& Jurutka, PW. (1998). The nuclear vitamin D receptor: Biological and molecular regulatory properties revealed. Journal of Bone and Mineral Research, 13(3), 325-349.

Link to publication record in Ulster University Research Portal

\section{Published in:}

Journal of Bone and Mineral Research

Publication Status:

Published (in print/issue): 01/03/1998

\section{Document Version}

Publisher's PDF, also known as Version of record

\section{General rights}

Copyright for the publications made accessible via Ulster University's Research Portal is retained by the author(s) and / or other copyright owners and it is a condition of accessing these publications that users recognise and abide by the legal requirements associated with these rights.

\section{Take down policy}

The Research Portal is Ulster University's institutional repository that provides access to Ulster's research outputs. Every effort has been made to ensure that content in the Research Portal does not infringe any person's rights, or applicable UK laws. If you discover content in the Research Portal that you believe breaches copyright or violates any law, please contact pure-support@ulster.ac.uk. 


\title{
Review
}

\section{The Nuclear Vitamin D Receptor: Biological and Molecular Regulatory Properties Revealed}

\author{
MARK R. HAUSSLER, G. KERR WHITFIELD, CAROL A. HAUSSLER, JUI-CHENG HSIEH, \\ PAUL D. THOMPSON, SANFORD H. SELZNICK, CARLOS ENCINAS DOMINGUEZ, and \\ PETER W. JURUTKA
}

\section{INTRODUCTION}

$I^{N}$ NHE DECADE Since the Vitamin D RECEPTOR (VDR) was cloned $^{(1)}$ and recognized as a member of the superfamily of nuclear receptors that regulate gene expression in a ligand-dependent manner, ${ }^{(2,3)}$ the central role of VDR in the biology of vitamin D action has been illuminated and is being defined at the molecular level. Following renal production as the hormonal metabolite of vitamin $\mathrm{D}, 1 \alpha, 25$-dihydroxyvitamin $\mathrm{D}_{3}\left(1,25(\mathrm{OH})_{2} \mathrm{D}_{3}\right)$ functions as the ligand for VDR, with the hormone-receptor complex inducing calcemic and phosphatemic effects that result in normal bone mineralization and remodeling. VDR not only mediates the action of $1,25(\mathrm{OH})_{2} \mathrm{D}_{3}$ in calcium/phosphate translocating tissues, primarily intestine, but also elicits a myriad of apparent bioactivities in other major cell systems in the organism, including immune, neural, epithelial, and endocrine. The scope of this review will be limited to highlighting the actions of $1,25(\mathrm{OH})_{2} \mathrm{D}_{3}$ mediated by nuclear VDR and discussing new developments in the structure/function analysis of the receptor, including the phenotype of VDR knockout mice and the biochemical classification of patients with point mutations in the receptor. These new advances, along with other recent research, will be interpreted to update our understanding of the molecular role of VDR, ranging from characterization of its natural gene and clinically significant polymorphisms, through its DNA contact sites and protein partners, to novel ligand analogs that hold the promise of influencing VDR conformation in a therapeutically beneficial fashion.

\section{VDR BIOLOGY}

Pathophysiology of the vitamin D endocrine system and bone mineral metabolism

The traditional action of vitamin $\mathrm{D}$, via its $1,25(\mathrm{OH})_{2} \mathrm{D}_{3}$ hormonal metabolite, is to effect calcium and phosphate homeostasis to ensure the deposition of bone mineral (summarized in Fig. 1A). 1,25(OH $)_{2} \mathrm{D}_{3}$ stimulates intestinal calcium and phosphate absorption, bone calcium and phosphate resorption, and renal calcium and phosphate reabsorption, thus increasing the blood $\mathrm{Ca} \cdot \mathrm{PO}_{4}$ ion product. Failure to achieve normal bone mineral accretion by these mechanisms leads to rachitic syndromes. Nutritional rickets, caused by the simultaneous deprivation of sunlight exposure $^{(4)}$ and dietary vitamin D, was ameliorated in classic experiments by administration of this fat soluble vitamin (reviewed in Ref. 5). Subsequently, it was recognized that the pathways comprising the metabolic activation of the vitamin to its hormonal form and consequent functions of the hormone in target tissues (Fig. 1) present additional steps where defects directly elicit vitamin D-resistant rachitic syndromes. Two such disorders involve the inadequate bioactivation of 25 -hydroxyvitamin $\mathrm{D}_{3}\left(25(\mathrm{OH}) \mathrm{D}_{3}\right)$, a constitutively produced intermediary metabolite, to 1,25 $(\mathrm{OH})_{2} \mathrm{D}_{3}$. This step is catalyzed by the $1 \alpha$-OHase enzyme in kidney (Fig. 1A). Chronic renal failure results in renal rickets and secondary hyperparathyroidism when compromised renal mass reduces $1 \alpha$-OHase activity, ${ }^{(6)}$ whereas pseudo-vitamin D-deficiency rickets (PDDR) involves a specific hereditary defect in the gene coding for the $1 \alpha$ OHase enzyme. ${ }^{(7)}$ The latter conclusion has been verified by the recent cloning of cDNAs for the rat ${ }^{(8)}$ and mouse $^{(9)}$

Department of Biochemistry, College of Medicine, The University of Arizona, Tucson, Arizona, U.S.A. 
A.

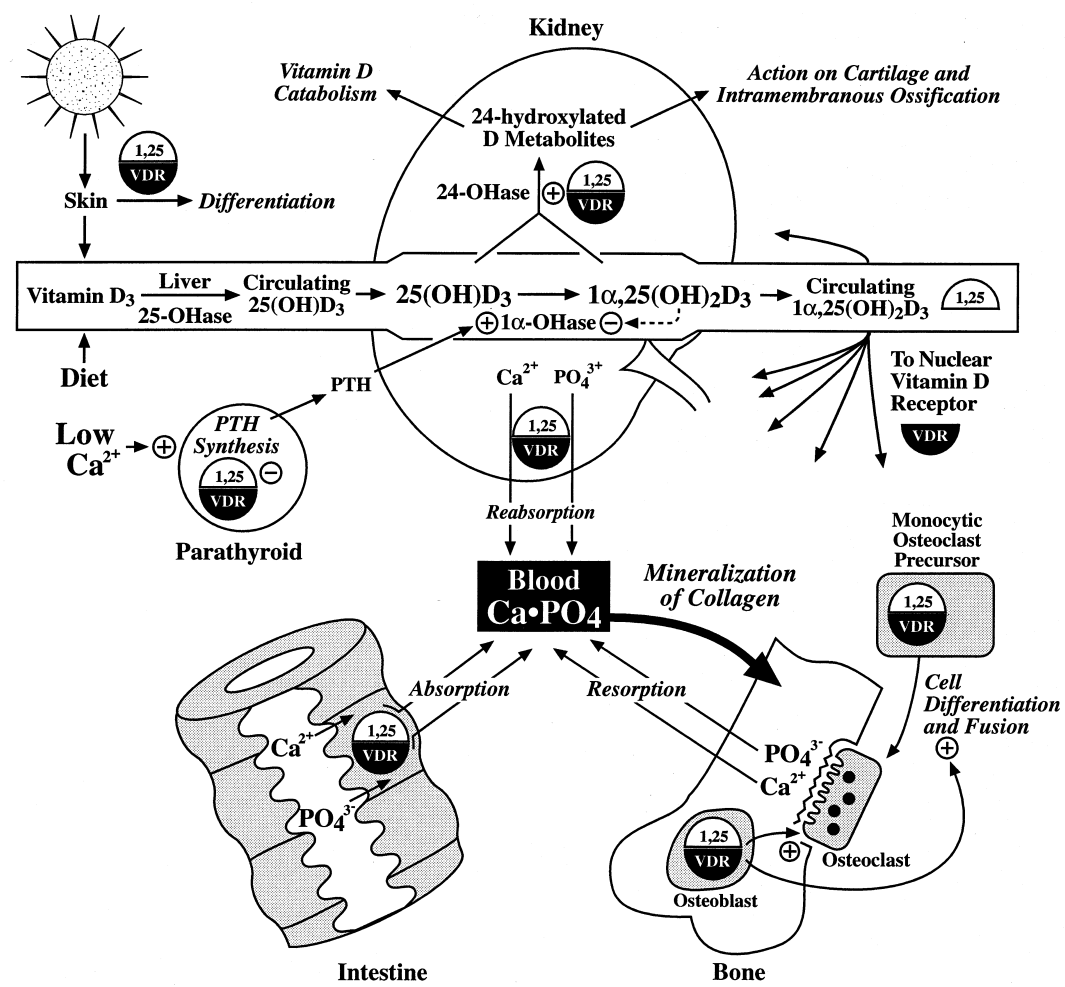

B.

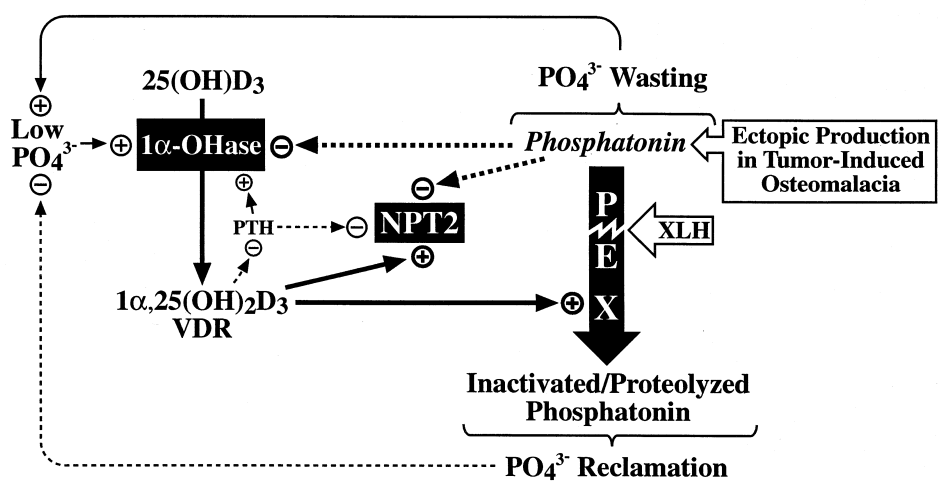

FIG. 1. Calcemic and phosphatemic biological actions of vitamin D in mammals. (A) Effects of vitamin D and its metabolites to ensure skeletal integrity, especially when calcium is limiting. (Central open box) Vitamin $\mathrm{D}_{3}$, obtained from diet or derived from sunlight-initiated photobiogenesis in skin, is converted via two hydroxylation reactions to the $1,25(\mathrm{OH})_{2} \mathrm{D}_{3}$ hormonal form that circulates in blood. The final step in bioactivation of vitamin to hormone is catalyzed by the renal $1 \alpha$-OHase when stimulated by PTH under conditions of low calcium. (Lower portion) Integrated actions of the $1,25(\mathrm{OH})_{2} \mathrm{D}_{3}$ metabolite, via binding to the intracellular VDR, to control calcium homeostasis in bone, intestine, kidney, and parathyroid as explained in the text. (Top left) Action of $1,25(\mathrm{OH})_{2} \mathrm{D}_{3}-\mathrm{VDR}$ in skin cell differentiation. (Top center) Conversion of $1,25(\mathrm{OH})_{2} \mathrm{D}_{3}$ or the preceding $25(\mathrm{OH}) \mathrm{D}_{3}$ metabolite to 24-hydroxylated forms in response to $1,25(\mathrm{OH})_{2} \mathrm{D}_{3}-\mathrm{VDR}$ induction of the 24-OHase gene. This conversion serves to initiate catabolism of the vitamin $\mathrm{D}$ molecule, but may also produce 24-hydroxylated metabolites with novel hormonal activity with respect to chondrocyte differentiation and bone mineralization (see text). (B) The vitamin D bioactivation-phosphate homeostatic loop: proposed novel roles for phosphatonin, the PEX gene product, and NPT2. (Left and lower portion) Under normal physiologic conditions, low $\mathrm{PO}_{4}$ enhances the synthesis of $1,25(\mathrm{OH})_{2} \mathrm{D}_{3}$, which then acts through VDR to effect phosphate reclamation by suppressing PTH as well as inducing NPT2 and PEX gene expression. NPT2 acts directly to reabsorb $\mathrm{PO}_{4}$, while the PEX enzyme eliminates phosphatonin. (Top right) Tumor-induced osteomalacia and XLH each elicit increased phosphatonin, an uncharacterized phosphaturic hormone that is postulated to inhibit both NPT2 and the $1 \alpha$-OHase, to cause severe phosphate wasting. 
$1 \alpha$-OHase $\mathrm{P}_{450}$ and the pinpointing of the human $1 \alpha$ OHase gene to a chromosomal locus coincident with PDDR. ${ }^{(8)}$ Interestingly, the $1 \alpha$-OHase/PDDR locus maps rather closely to the VDR gene on chromosome 12 in the 12q13-14 region, ${ }^{(7)}$ a proximity that may be relevant to the evolution and control of the vitamin D ligand-receptor system.

\section{Hypocalcemic $1,25(\mathrm{OH})_{2} \mathrm{D}_{3}$ resistance}

Clinical and molecular genetic data from the last decade have provided unequivocal evidence for the obligatory role of VDR in mediating the action of vitamin D. Familial target tissue insensitivity to $1,25(\mathrm{OH})_{2} \mathrm{D}_{3}$, known as hereditary hypocalcemic vitamin D-resistant rickets (HVDRR), is an autosomal recessive disorder resulting in a phenotype characterized by severe bowing of the lower extremities, short stature, and often alopecia. ${ }^{(10)}$ In virtually all cases, the cause of this syndrome has been shown to be a defect in the gene encoding human VDR (hVDR) (reviewed in Refs. 10-13), although potential exceptions have been described. ${ }^{(14,15)}$ The fact that the phenotype of HVDRR patients, excluding alopecia, mimics classic nutritional rickets indicates that $1,25(\mathrm{OH})_{2} \mathrm{D}_{3}$-liganded VDR not only executes all of the bone mineral homeostatic actions of $1,25(\mathrm{OH})_{2} \mathrm{D}_{3}$ but suggests that VDR itself also participates in the normal hair growth cycle in skin.

\section{Generation of VDR null mice}

Recently, VDR knockout mice have been created by two groups, ${ }^{(16,17)}$ revealing apparently normal heterozygotes but homozygotes that display a phenotype very similar to HVDRR, including the progressive development of alopecia over 4-7 weeks of age. At various intervals after birth (differing somewhat between the two studies), VDR null mice acquired low bone mass, hypocalcemia, hypophosphatemia, hyperparathyroidism, and 10-fold elevated 1,25$(\mathrm{OH})_{2} \mathrm{D}_{3}$, coincident with extremely low $24,25(\mathrm{OH})_{2} \mathrm{D}_{3}$. Affected homozygotes died within 15 weeks ${ }^{(16)}$ or exhibited near normal survival rates for up to 6 months. ${ }^{(17)}$ The differing survival times may be related to diet or environmental variations, since ablation of exon II/first zinc finger $^{(16)}$ or exon III/second zinc finger ${ }^{(17)}$ should produce equivalent functional consequences of VDR gene knockout. Despite a lack of VDR throughout early development, VDR null mice are born phenotypically normal, exhibiting symptoms of rickets/osteomalacia and secondary hyperparathyroidism primarily after weaning. ${ }^{(16)}$ This observation suggests that the vitamin D endocrine system is principally required for maintaining bone mineral homeostasis when the organism is deprived of a consistent and plentiful supply of calcium, such as occurs after weaning in mammals, after hatching in birds, or after leaving the aqueous environment in the case of amphibians. ${ }^{(18)}$

In addition to the data reported in their abstract, Demay and coworkers ${ }^{(19)}$ also presented preliminary results describing the prevention of many, but not all, of the phenotypic effects of VDR knockout by means of a "rescue diet," consisting of high levels of lactose, calcium, and phosphate. By manipulating blood calcium and phosphate levels in this manner, parathyroid hormone (PTH) was normalized and bone mineralization was greatly improved in the VDR knockout animals, to a degree that the histology of the growth plate was indistinguishable from that of normal littermates. However, alopecia and skin abnormalities, such as dermal cysts, persisted in the VDR null mice on the rescue diet, intimating that VDR plays an indispensable role in hair and skin development independent of bone mineral homeostasis. That normalizing circulating mineral concentrations via dietary intervention in VDR knockout mice prevents the rachitic phenotype is consistent with results in HVDRR patients whose bone abnormalities are resolved by frequent therapy with overnight intravenous calcium infusions. ${ }^{(20,21)}$

Thus, the generation of VDR null mice and the reversal of their bone abnormalities by diet dramatizes the concept that the major physiologic effect of $1,25(\mathrm{OH})_{2} \mathrm{D}_{3}$ is on intestinal absorption of calcium and phosphate, although certain calcium regulating end-points such as depressed renal calbindin- $\mathrm{D}_{9 \mathrm{k}}$ mRNA expression in kidney are not corrected when VDR null mice are maintained on the rescue diet (M. Demay et al., unpublished results). Moreover, in another preliminary study, Kato and colleagues ${ }^{(22)}$ found that, when utilizing the coculture system of Suda and coworkers, ${ }^{(23)}$ osteoblasts/stromal cells from VDR knockout mice will not support $1,25(\mathrm{OH})_{2} \mathrm{D}_{3}$-induced osteoclastogenesis of normal spleen cells, whereas the reverse experiment (normal osteoblasts/stromal cells and VDR null mouse spleen cells) results in the production of osteoclasts upon exposure of the coculture to $1,25(\mathrm{OH})_{2} \mathrm{D}_{3}$. Therefore, as depicted in Fig. 1(A), VDR appears to be essential for $1,25(\mathrm{OH})_{2} \mathrm{D}_{3}$ to elicit a paracrine signal from osteoblasts, which in turn facilitates osteoclast differentiation, at least in vitro. However, the fact that VDR null mice curiously possess normal, or even increased numbers of osteoclasts $^{(16)}$ suggests that other osteoclast-activating factors, such as PTH or interleukin-1 (IL-1), can still support osteoclastogenesis in the absence of functional VDR.

\section{The participation of VDR in feedback control of the vitamin $D$ endocrine system}

Superimposed upon its pivotal role in controlling bone mineral transport and differentiation in hair follicles, another function of the $1,25(\mathrm{OH})_{2} \mathrm{D}_{3}-\mathrm{VDR}$ complex is to govern the level of the renal $1,25(\mathrm{OH})_{2} \mathrm{D}_{3}$ hormone by feedback regulation of its biosynthesis and by induction of a key catabolic enzyme. $1,25(\mathrm{OH})_{2} \mathrm{D}_{3}$ appears to effect a short feedback loop (Fig. 1A) to repress the $1 \alpha$-OHase enzyme, ${ }^{(24)}$ and is also a potent suppressor of the synthesis and secretion of $\mathrm{PTH},{ }^{(25)}$ the primary tropic hormone stimulating the $1 \alpha$-OHase (Fig. 1). ${ }^{(26)}$ The mechanism whereby $1,25(\mathrm{OH})_{2} \mathrm{D}_{3}$ curtails PTH production involves a VDRmediated silencing of PTH gene transcription. ${ }^{(27-29)}$ Based upon preliminary data from dietarily rescued VDR null mice, excess calcium is able to adequately control PTH secretion and parathyroid cell growth, suggesting that the role of $1,25(\mathrm{OH})_{2} \mathrm{D}_{3}$ in these processes is cooperative with physiologic calcium levels but can be overridden in situations of calcium abundance. 
Catabolism of $1,25(\mathrm{OH})_{2} \mathrm{D}_{3}$ and generation of 24hydroxylated vitamin $D$ metabolites

Turnover of $1,25(\mathrm{OH})_{2} \mathrm{D}_{3}$ is accomplished via several catabolic routes, ${ }^{(30,31)}$ with 24 -hydroxylation initiating the apparent primary pathway for elimination of vitamin D metabolites. The 24-OHase enzyme is markedly enhanced by $1,25(\mathrm{OH})_{2} \mathrm{D}_{3}$ through a VDR-dependent mechanism (Fig. 1A), a phenomenon predominating in kidney but also occurring in all $1,25(\mathrm{OH})_{2} \mathrm{D}_{3}$ target cells. ${ }^{(32,33)}$ The dependency of 24-OHase activity on VDR action is emphasized by the extremely low levels of 24-hydroxylated metabolites found in VDR null mice, as discussed above. ${ }^{(16)}$ Both the 25$(\mathrm{OH}) \mathrm{D}_{3}$ precursor and the $1,25(\mathrm{OH})_{2} \mathrm{D}_{3}$ hormone serve as effective substrates for the 24-OHase enzyme, rendering the latter capable of catalyzing a potent attenuation of active vitamin $\mathrm{D}$ metabolite concentrations. In fact, homozygous 24-OHase null mice ${ }^{(34)}$ display reduced 1,25$(\mathrm{OH})_{2} \mathrm{D}_{3}$ clearance, with the F1 progeny exhibiting signs of vitamin $\mathrm{D}$ intoxication, such as calcified kidneys. Interestingly, the F1 progeny also have defective intramembranous ossification. The failure of bones such as the calvaria and mandible to calcify in this situation could be a developmental consequence of excess $1,25(\mathrm{OH})_{2} \mathrm{D}_{3}$. Another possibility is that a 24-hydroxylated D-metabolite(s) is required for some aspect of cartilage or bone formation (Fig. 1A), ${ }^{(35-38)}$ perhaps via pharmacokinetic interactions with 1,25$(\mathrm{OH})_{2} \mathrm{D}_{3}$ or through an uncharacterized novel receptor for the 24-hydroxylated metabolite.

\section{The role of $1,25(\mathrm{OH})_{2} \mathrm{D}_{3}-\mathrm{VDR}$ in phosphate homeostasis}

Other than negative feedback on PTH synthesis and secretion $^{(27,39)}$ to suppress this phosphaturic hormone, how does the $1,25(\mathrm{OH})_{2} \mathrm{D}_{3}-\mathrm{VDR}$ complex influence phosphate metabolism to maintain the $\mathrm{Ca} \cdot \mathrm{PO}_{4}$ ion product? One mechanism seems to be the primary induction of phosphate translocating proteins in kidney and perhaps intestine (Fig. 1). An example is the renal sodium-phosphate cotransporter-2 (NPT2) (Fig. 1B), ${ }^{(40,41)}$ a likely $1,25(\mathrm{OH})_{2} \mathrm{D}_{3}$ induced protein because its gene contains a vitamin $\mathrm{D}$ responsive element (VDRE) in the promoter region (see below). It is also well established that hypophosphatemia stimulates the $1 \alpha$-OHase (Fig. $1 \mathrm{~B}$ ) to elevate circulating $1,25(\mathrm{OH})_{2} \mathrm{D}_{3}$ levels. ${ }^{(26)}$ However, circulating $1,25(\mathrm{OH})_{2} \mathrm{D}_{3}$ is inappropriately low for the prevailing phosphate concentrations in patients with $\mathrm{X}$-linked hypophosphatemic rickets $(\mathrm{XLH}),{ }^{(42)}$ a dominant familial disorder of renal phosphate wasting. Importantly, such patients can be cured with a therapeutic combination of oral phosphate and 1,25$(\mathrm{OH})_{2} \mathrm{D}_{3} \cdot{ }^{(43)}$ The defective gene responsible for XLH has been identified as PEX, or phosphate-regulating gene with homologies to endopeptidases located on the $\underline{X}$-chromosome. ${ }^{(44)}$ Further, there exists a significant number of cases of tumor-induced osteomalacia, an acquired disorder that closely resembles the phosphate wasting of XLH and is characterized by low circulating $1,25(\mathrm{OH})_{2} \mathrm{D}_{3} \cdot{ }^{(45)}$ Finally, renal cross-transplantation ${ }^{(46)}$ and parabiosis ${ }^{(47)}$ studies in normal and genetically hypophosphatemic mice demon- strate that a novel uncharacterized phosphaturic hormone is present in the circulation. Taken together, these observations argue strongly that the XLH and tumor-induced osteomalacia syndromes are both caused by excess amounts of this novel humoral factor, which is distinct from PTH and has been named phosphatonin (Fig. 1B). ${ }^{(48,49)}$ Like PTH, phosphatonin is presumably a potent inactivator of NPT2 (Fig. 1B), but in contrast to $\mathrm{PTH}$, this newly recognized factor apparently also inhibits the $1 \alpha$-OHase, thus suppressing $1,25(\mathrm{OH})_{2} \mathrm{D}_{3}$. As depicted in Fig. 1(B), the normal role of the PEX gene product is postulated to be the proteolytic inactivation of this phosphaturic principle, such that inactivating PEX mutations in XLH elicit the appearance of abnormally high circulating levels of phosphatonin. ${ }^{(4)}$ In the case of tumor-induced osteomalacia, the tumor appears to produce phosphatonin ectopically. Thus, as illustrated in Fig. 1(B), the PEX/phosphatonin system could participate in a novel regulatory loop for maintaining normal phosphate homeostasis, which becomes deranged in XLH, or when tumors directly secrete phosphatonin.

Another role of $1,25(\mathrm{OH})_{2} \mathrm{D}_{3} / \mathrm{VDR}$ in phosphate control is postulated to be the induction of PEX gene expression (Fig. 1B), thus creating an additional strategy for protection by $1,25(\mathrm{OH})_{2} \mathrm{D}_{3}$ against hypophosphatemia. Indeed, the PEX gene appears to possess a VDRE based upon Southwestern analysis of the relevant yeast artificial chromosome. ${ }^{(50)}$ The present hypothesis is that a low phosphate level triggers an increase in circulating $1,25(\mathrm{OH})_{2} \mathrm{D}_{3}$, which in turn augments the PEX gene product to destroy phosphatonin, constituting a novel phosphate homeostatic loop that is overwhelmed when high levels of phosphatonin diminish $1,25(\mathrm{OH})_{2} \mathrm{D}_{3}$ synthesis and inhibit NPT2. This concept is consistent with the relatively depressed 1,25 $(\mathrm{OH})_{2} \mathrm{D}_{3}$ levels observed either in patients with tumorinduced osteomalacia or in kindreds with XLH caused by inactivating PEX mutations. Given the present indications that phosphatonin represents a pathophysiologically relevant phosphaturic hormone that regulates vitamin $\mathrm{D}$ bioactivation, its characterization at the chemical level is eagerly anticipated.

\section{Neoclassical $1,25(\mathrm{OH})_{2} D_{3} / V D R$ actions}

As summarized in Table 1, the potential actions of $1,25(\mathrm{OH})_{2} \mathrm{D}_{3}$ via its nuclear VDR extend far beyond the bone mineral homeostasis realm pictured in Fig. 1. The following three independent methodologies have been employed to provide evidence that $1,25(\mathrm{OH})_{2} \mathrm{D}_{3}$ functions in a diverse array of cells: autoradiographic localization of the ligand following administration to vitamin D-deficient animals, immunohistochemical detection of VDR in the nucleus of target cells, and responsiveness of specific cell types in culture to $1,25(\mathrm{OH})_{2} \mathrm{D}_{3}$ and its active analogs. In many cases, these data are coupled to biological responses or to loss of function in VDR null mice, in vivo, for instance in the maintenance of insulin secretion by $1,25(\mathrm{OH})_{2} \mathrm{D}_{3},{ }^{(51)}$ the uterine hypoplasia reported in VDR knockout female mice apparently caused by suboptimal ovarian estrogen production, ${ }^{(16)}$ and the exploitation of the prodifferentia- 
Table 1. Neoclassical $1,25(\mathrm{OH})_{2} \mathrm{D}_{3}$ Target Sites

\begin{tabular}{|c|c|c|}
\hline Classification & Target tissue or cell* & Specific effects ${ }^{\dagger}$ \\
\hline Immune system & $\begin{array}{l}\text { monocytes/macrophages }{ }^{(53)} \text { and } \mathrm{T}- \\
\text { lymphocytes (helper type } 1)^{(53,57)}\end{array}$ & $\begin{array}{l}\text { suppression of } \gamma \text {-interferon }{ }^{(202)} \text { and IL-1 through } \\
\text { IL- }^{(53,159,203)}\end{array}$ \\
\hline $\begin{array}{l}\text { Central nervous } \\
\text { system }\end{array}$ & $\begin{array}{l}\text { dorsal root ganglia, }{ }^{(204)} \text { glial cells, and } \\
\text { hippocampus }\end{array}$ & $\begin{array}{l}\text { production of NGF, }{ }^{(65,66,205)} \text { neurotrophin-3, }{ }^{(64)} \\
\text { and leukemia inhibitory factor }\end{array}$ \\
\hline \multirow[t]{7}{*}{ Epithelium } & epidermal skin/keratinocyte ${ }^{(206)}$ & differentiation $^{(17,211)}$ \\
\hline & hair follicle ${ }^{(207)}$ & differentiation $^{(16,17,212)}$ \\
\hline & female reproductive tract ${ }^{(208)}$ & uterine development ${ }^{(16)}$ \\
\hline & $\operatorname{mammary}^{(108)}$ & $\downarrow$ cell growth ${ }^{(213)}$ \\
\hline & prostate $^{(209)}$ & 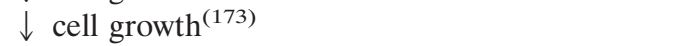 \\
\hline & colon $^{(210)}$ & $\downarrow$ cell $\operatorname{growth}^{(170,214)}$ \\
\hline & $\operatorname{lung}^{(108)}$ & surfactant $^{(215)}$ \\
\hline \multirow[t]{4}{*}{ Endocrine system } & thyrotrope $\mathrm{e}^{(216)}$ & TRH receptor ${ }^{(218)}$ \\
\hline & thyroid $^{(108)}$ & $\downarrow$ TSH action $^{(219)}$ \\
\hline & pancreatic $\beta$-cell ${ }^{(217)}$ & insulin secretion $^{(51)}$ \\
\hline & ovary $^{(208)}$ & folliculogenesis $^{(16)}$ and $\downarrow$ cell growth $^{(220)}$ \\
\hline Muscle & heart $^{(221)}$ & $\downarrow \mathrm{ANP}^{(222,223)}$ \\
\hline Adipose & $\operatorname{adipocyte}^{(224)}$ & lipoprotein lipase ${ }^{(225)}$ \\
\hline Many systems & diverse cells and cancer cell lines ${ }^{(173,226,227)}$ & $\begin{array}{l}\downarrow \text { cell growth }\left(\mathrm{c}-f o s^{(179)} ; \downarrow \mathrm{c}-m y c^{(58,157)}\right), \\
\text { differentiation }\left(\mathrm{p} 21^{(228)} ; \mathrm{p} 27^{(229)} ; \operatorname{Mad}_{-1}{ }^{(230)}\right) \\
\text { and apoptosis }\end{array}$ \\
\hline
\end{tabular}

*Detected by autoradiographic ligand localization in the nucleus, VDR immunocytochemistry, or responsiveness of cultured cells.

${ }^{\dagger}$ Effects of $1,25(\mathrm{OH})_{2} \mathrm{D}_{3}$ are positive unless otherwise noted and are selected examples rather than a comprehensive list.

tion/antiproliferative actions of $1,25(\mathrm{OH})_{2} \mathrm{D}_{3}$ in the treatment of psoriasis. ${ }^{(52)}$

One major neoclassical target for $1,25(\mathrm{OH})_{2} \mathrm{D}_{3}$ is the immune system (reviewed in Ref. 53), with the suppression of IL-1 to IL- 6 and interferon- $\gamma$ constituting prominent in vitro $1,25(\mathrm{OH})_{2} \mathrm{D}_{3}$ effects mediated by VDR (Table 1 ). Moreover, in vivo immunomodulatory actions of the hormone also have been documented (reviewed in Ref. 54), such as reduced macrophage and lymphocyte function in vitamin $\mathrm{D}$-deficient rats. ${ }^{(55)} 1,25(\mathrm{OH})_{2} \mathrm{D}_{3}$ functions as a general suppressor of the immune system, especially of T-helper cells (subset type 1), suggesting that analogs of vitamin D might be useful therapeutic agents in procedures such as organ transplants ${ }^{(56)}$ or in the treatment of autoimmune disorders. ${ }^{(57)}$ In addition, $1,25(\mathrm{OH})_{2} \mathrm{D}_{3}$ is thought to play an important role in the differentiation of cells in the hematopoietic lineage. Several illustrations of this action have been reported, including differentiation of a human promyelocytic leukemia cell line (HL-60) into macrophagelike cells, ${ }^{(58,59)}$ and the development of osteoclasts in bone from colony forming unit-granulocyte/macrophage precursors (see Ref. 53 and references therein). Many of these effects of $1,25(\mathrm{OH})_{2} \mathrm{D}_{3}-\mathrm{VDR}$, although of potential therapeutic significance, may be biologically redundant with other immune modulators, perhaps offering survival advantages. The tentative conclusion of redundant immunoregulation is based upon the normal immune profile of VDR null mice at 7 weeks of age, ${ }^{(16)}$ but it is reasonable to hypothesize that the potential immunomodulatory power of $1,25(\mathrm{OH})_{2} \mathrm{D}_{3}-\mathrm{VDR}$ could become more significant during pathophysiological stress situations or under conditions of senescence.
Other apparent sites of action for $1,25(\mathrm{OH})_{2} \mathrm{D}_{3}$ and VDR include the central nervous system (CNS) (Table 1), where one of the outcomes is immunosuppression. For example, $1,25(\mathrm{OH})_{2} \mathrm{D}_{3}$ treatment elicits a partial improvement of symptoms in rodents with developing experimental allergic encephalomyelitis. ${ }^{(60,61)}$ Moreover, $1,25(\mathrm{OH})_{2} \mathrm{D}_{3}$ also has been shown to induce expression of the following neurotrophic hormones or their mRNAs: glial cell-derived neurotrophic factor (a protein that may be important in protecting certain types of neural tissue from degenerative processes), ${ }^{(62)}$ leukemia inhibitory factor (a widely distributed protein in the brain with neurotrophic activity), ${ }^{(63)}$ neurotrophin-3 mRNA (in primary astrocytes), ${ }^{(64)}$ and nerve growth factor (both in primary newborn astrocytes ${ }^{(65)}$ and in the hippocampus and cortex of the adult rat ${ }^{(66)}$ ). Furthermore, the activity of cholinergic acetyltransferase is elevated in specific brain regions in response to 1,25 $(\mathrm{OH})_{2} \mathrm{D}_{3}$ administration. ${ }^{(67)}$ In some neurons, analogous to the antiapoptotic effect of calbindin- $\mathrm{D}_{28 \mathrm{k}}$ in lymphocytes, ${ }^{(68)}$ the induction of calbindins by $1,25(\mathrm{OH})_{2} \mathrm{D}_{3}$ may protect against cell death in the face of repetitive calcium transients, ${ }^{(69)}$ and in fact the expression of calbindin- $\mathrm{D}_{28 \mathrm{k}}$ mRNA is decreased in the hippocampus of Alzheimer's patients as assessed by in situ hybridization. ${ }^{(70,71)}$ Taken together, these observations not only imply a modulatory role for VDR in neural cell growth and differentiation but also intimate a possible role for $1,25(\mathrm{OH})_{2} \mathrm{D}_{3}$ in therapeutic intervention for neurodegenerative disorders.

Similarly, $1,25(\mathrm{OH})_{2} \mathrm{D}_{3}$ appears to affect dramatically the maturation and functions of certain normal and neoplastic epithelial cells (Table 1). As discussed above, VDR plays a 

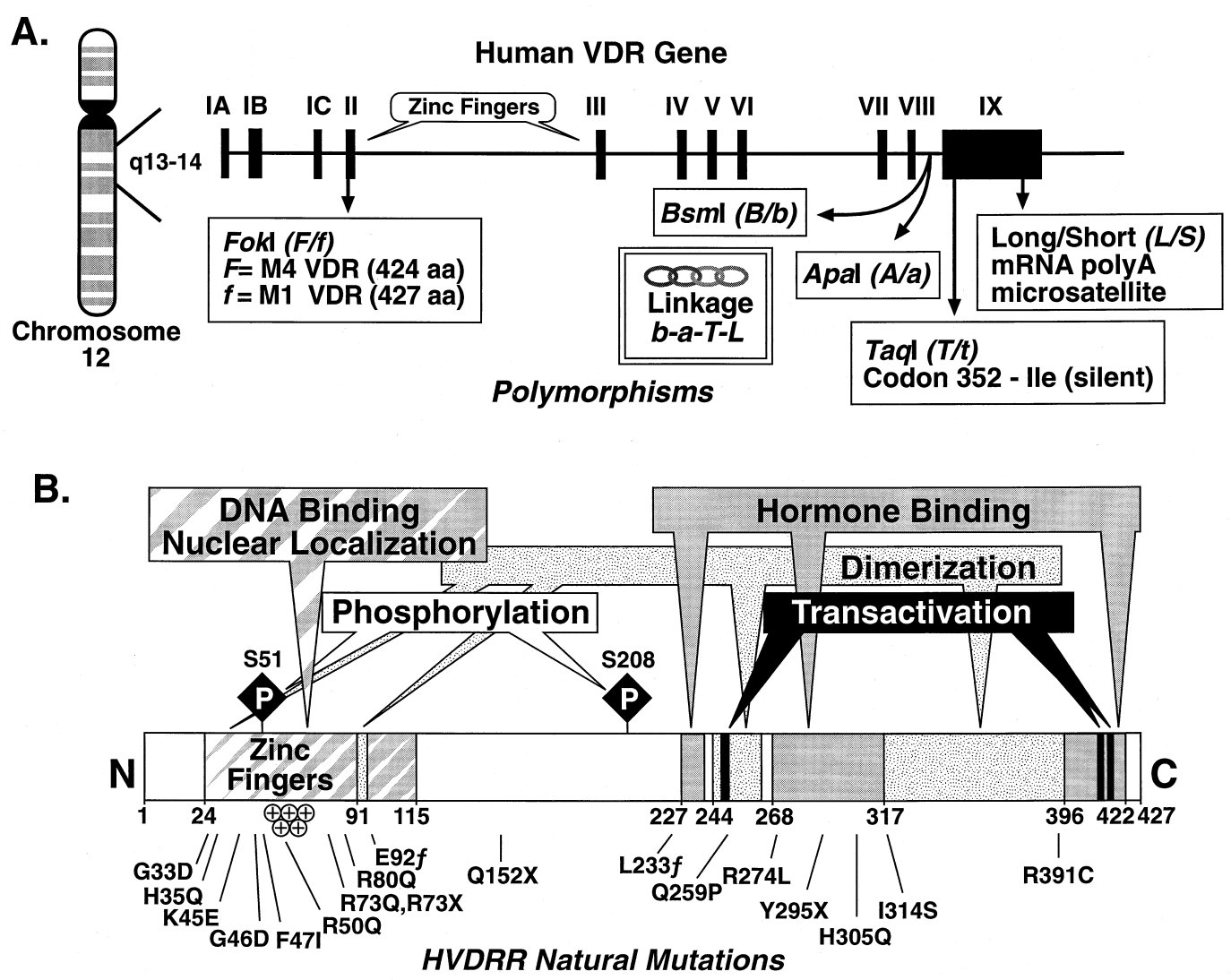

FIG. 2. Schematic view of genomic and deduced amino acid sequences for hVDR, displaying known natural variations. (A) The hVDR chromosomal gene, containing a total of 11 exons, three of which (IA, IB, and IC) encode $5^{\prime}$ UTR region and are variably present in VDR transcripts. ${ }^{(72)}$ Several polymorphic variants, including a FokI site in exon II, and a cluster of linked sites near or in exon IX, are discussed in the text. (B) Schematized linear amino acid sequence of hVDR, highlighting functional domains as currently understood from mutagenesis analysis. $\oplus$ signifies a cluster of five basic amino acids in the intervening sequence between the two zinc fingers. Two reported sites of modulatory serine phosphorylation at serine-51 and serine-208 are indicated by S51 and S208, respectively. Known natural point mutations in human patients with the HVDRR syndrome are indicated by single-letter abbreviations (e.g., G33D is a glycine to aspartate substitution at position 33). X refers to a premature stop codon, while $f$ indicates a frame-shift mutation, leading to premature termination. Point mutants from positions 33-80 are defective in DNA binding, and all X and $f$ mutants can neither bind hormone nor heterodimerize with RXR. Other point mutations in the C-terminal half of the receptor (from positions 259-391) display defects in either hormone-binding or heterodimer formation with RXR (or both) as discussed in the text.

key role in the hair growth cycle, an action related to the ability of $1,25(\mathrm{OH})_{2} \mathrm{D}_{3}$ to stimulate the differentiation of keratinocytes (Table 1). Also, the proliferation of a number of epithelially derived cancer cells (e.g., mammary, prostate, and colon) is inhibited in culture by $1,25(\mathrm{OH})_{2} \mathrm{D}_{3}$, with some cells being directed toward a more differentiated phenotype. This effect in neoplastic cells may be related to the reported ability of liganded VDR to arrest cells at the $\mathrm{G}_{1}$ stage by influencing cell cycle regulatory proteins, such as p21 and p27, to control cell growth transcription factors such as c-myc and c-fos, or to elicit apoptosis by downregulating $\mathrm{Bcl}-2$ (Table 1 and references therein). Therefore, the $1,25(\mathrm{OH})_{2} \mathrm{D}_{3}$ hormone seems to resemble its nutritionally derived, lipophilic ligand cousins, vitamin A and thyroid hormone, in possessing the ability to influence the program of cell development as well as to evoke classic metabolic and growth regulatory effects. $1,25(\mathrm{OH})_{2} \mathrm{D}_{3}$ also reportedly affects several major endocrine processes, such as TRH/TSH action and pancreatic insulin secretion (Table 1). However, only further investigations of VDR null mice and other transgenic strategies, such as tissue-specific expression of a dominant negative VDR, will allow us to sort out which of the putative neoclassical effects of $1,25(\mathrm{OH})_{2} \mathrm{D}_{3}$ mediated by VDR are biologically relevant. At this early juncture, of those sites enumerated in Table 1, only the skin/hair growth cycle and ovarian/uterine systems appear to be markedly affected in the VDR null mouse. However, the limited phenotype of VDR knockout mice does not preclude $1,25(\mathrm{OH})_{2} \mathrm{D}_{3}$ and its analogs from being valuable as biological response modifiers useful in the treatment of hyperproliferative disorders, autoimmunity, and CNS deterioration, as well as traditional maladies of calcium and phosphorus metabolism such as renal osteodystrophy, hypoparathyroidism, and osteoporosis. 


\section{STRUCTURE/FUNCTION OF THE VDR GENE AND PROTEIN}

\section{hVDR chromosomal gene}

The recently characterized gene encoding hVDR (Fig. 2A), ${ }^{(72)}$ previously localized to chromosome $12,{ }^{(73)}$ is similar to other nuclear receptor genes ${ }^{(74)}$ in that each of the two zinc fingers is encoded by separate exons (II and III), and the 5' end of the gene exhibits some complexity in the form of alternate splice and/or translation start sites. For hVDR, alternate splicing of three exons (IA-IC) encoding portions of the $5^{\prime}$ untranslated region generates at least three mRNA variants, ${ }^{(72)}$ while the presence of a polymorphic sequence in exon II determines the presence or absence of an alternative translation start site (see discussion of FokI polymorphism below). ${ }^{(72)}$ A unique feature of the hVDR gene is the presence of an additional exon (V) that is not found in other nuclear receptor genes (Fig. 2A $)^{(72)}$; it resides near the center of the gene and encodes residues 155-194 in hVDR. This region of the VDR protein is more expansive than the corresponding segment in other nuclear receptors, suggesting that the VDR may have acquired a novel exon of unknown function as it diverged evolutionarily from other nuclear receptor genes. ${ }^{(72)}$

\section{hVDR polymorphisms}

One of the most intriguing, yet controversial, areas of bone-related genetic research in the past few years has been the discovery of common polymorphisms in the hVDR gene and their potential relationship to bone mineral density (BMD) and the pathophysiology of osteoporosis, hyperparathyroidism, and cancers of the breast and prostate. Morrison, Eisman, and colleagues ${ }^{(75)}$ first reported that VDR alleles could predict BMD, contending that the occurrence of a BsmI restriction site (Fig. 2A, denoted $b$ ) in the intron separating exons VIII and IX of the gene (Fig. 2A) is associated with enhanced lumbar spine BMD. Conversely, the absence of the BsmI site (denoted B) in VDR was correlated with low BMD. In a population of Australian twins of Irish ancestry, Morrison et al. ${ }^{(75)}$ concluded that the VDR genotype ( $b$ vs. $B$ ) accounted for up to $75 \%$ of the genetic component of BMD, although a correction/partial retraction of this report appeared recently. ${ }^{(76)}$ Numerous subsequent studies with other population samples have found more modest, ${ }^{(77,78)}$ little if any, ${ }^{(79-82)}$ and even conflicting associations ${ }^{(83)}$ of the $B$ versus $b$ alleles with BMD. A meta-analytic approach ${ }^{(84)}$ that incorporated the results of 16 VDR polymorphic studies revealed a 1.5$2.5 \%$ decrease in BMD associated with $B B$ (versus $b b$ ) homozygotes, far less dramatic than the $12 \%$ effect originally proposed. ${ }^{(75)}$ Additional studies have also suggested a trend toward lower bone mass with the $B$ allele, ${ }^{(85-88)}$ but it has become clear that other confounding factors, such as age, estrogen status, ethnicity, and calcium intake, must be accounted for to reveal the true impact, if any, of this VDR polymorphism on BMD.

Further evaluation of the VDR gene has revealed a cluster of linked polymorphisms in the $3^{\prime}$ portion of the
VDR gene (Fig. 2A), ${ }^{(89)}$ including the aforementioned $B s m I$ site, a nearby $A p a$ I site (in the same intron), and a silent mutation within codon 352 of the ninth exon that alters a TaqI site. These VDR polymorphisms have been linked not only to variations in bone-specific parameters but also to a higher occurrence of sporadic primary hyperparathyroidism in patients with the $b$ allele, ${ }^{(90)}$ as well as to prostate cancer, which possesses a particularly strong association with the $T$ allele (lack of the TaqI site). ${ }^{(91)}$ However, given that none of these polymorphisms change the encoded VDR protein in any way, the explanation for these findings has been unclear. Recently, an additional genetic variation in the hVDR gene was found in the form of a microsatellite poly(A) repeat in the 3' UTR, approximately $1 \mathrm{~kb}$ upstream of the poly(A) tail (Fig. 2A). Multiple ( $\geq 12)$ allelic variants of this microsatellite were detected and classified into two groupings, long $(L)$ and short $(S)$, based upon the length of the repeat. ${ }^{(92,93)}$ The $L$ grouping (linked to $T$; see Fig. 2A) exhibits a strong association with prostate cancer incidence ${ }^{(93)}$ but displays a contrasting protective effect against breast cancer. ${ }^{(94)}$ It is still not established whether this poly(A) microsatellite is the functionally relevant locus, although by analogy to short tandem repeats in other genes ${ }^{(95)}$ the length of the repeat may affect a crucial parameter, such as mRNA stability. Alternatively, the poly(A) microsatellite may be tightly linked to yet another site which is the true functional locus. Regardless of which scenario is correct, a complicating factor in interpreting earlier findings using the BsmI, TaqI, or Apa I polymorphic restriction sites is that the linkage is imperfect between these restriction sites and the $L$ versus $S$ groupings, such that some ethnic groups exhibit a very tight linkage (thus displaying a clear correlation between BMD and the Bsm I site), while in others (e.g., African-Americans) the presence of the BsmI or TaqI site is not a good predictor of the $L$ versus $S$ genotype, ${ }^{(92)}$ leading to a loss of functional correlation between BsmI or TaqI and BMD. Nonetheless, the study of the poly(A) microsatellite sequence may have brought us closer to a functional understanding of VDR genetic diversity, while also providing a partial explanation for the variability in association of Bsm I or TaqI genotypes with BMD and hyperproliferative disorders.

Near the 5' end of the hVDR gene, a FokI restriction endonuclease site has been identified, ${ }^{(96,97)}$ the presence of which (denoted $f$ ) dictates that the 427-residue, M1 isoform of VDR is expressed (so named because it contains an ATG methionine translational start site corresponding to codon \#1). An evolutionarily more recent polymorphism (Fig. 3), ${ }^{(98)}$ or neomorph, has been reported in which both the FokI restriction site and the ATG codon \#1 are changed, causing an alternative 424-residue isoform of the receptor to be translated. The $F$ neomorph, encoding M4 hVDR (for initiation of translation at the fourth codon) already constitutes approximately $65 \%$ of VDR alleles in human subjects (L. Remus and M. Haussler, unpublished results), intimating an evolutionary advantage in humans. The FokI polymorphism, which is not linked to the aforementioned cluster of variations in the $3^{\prime}$ region of the gene, may therefore have significance for human bone pathology. Indeed, the M4 isoform is more transcriptionally active 

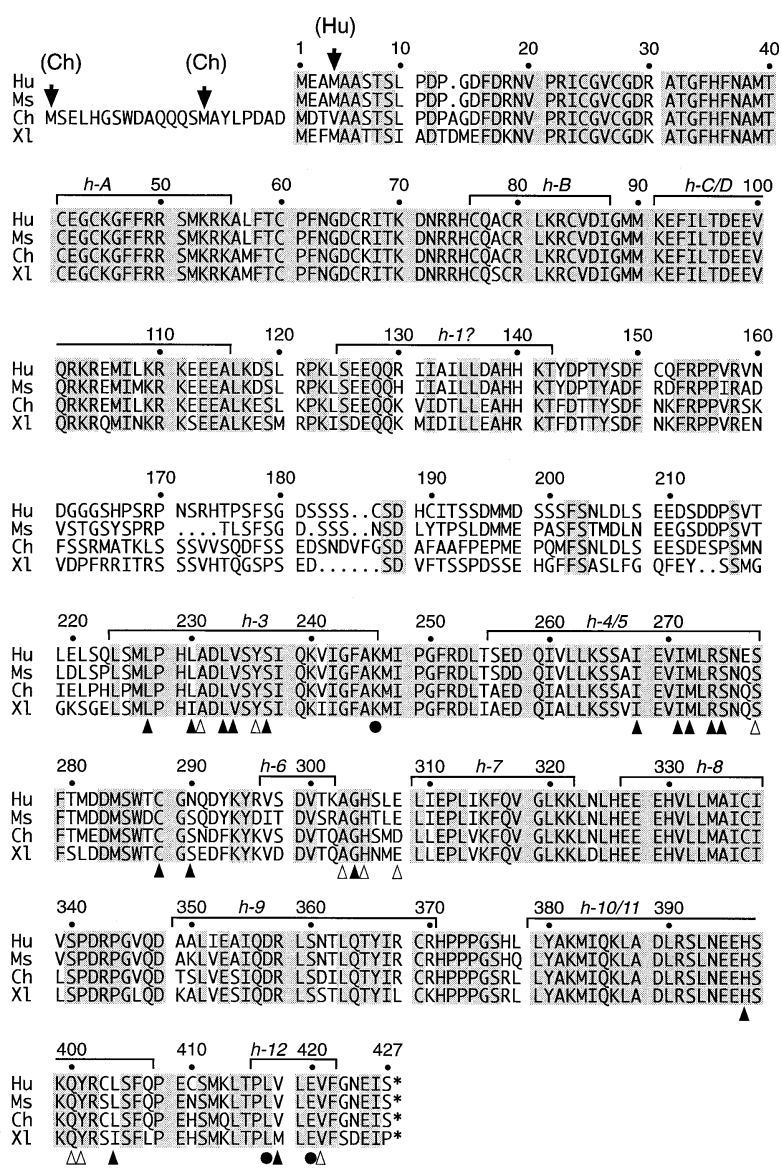

FIG. 3. Amino acid comparison among four of the six VDRs cloned to date. Shown are sequences from human $(\mathrm{Hu}),{ }^{(147)}$ mouse (Mus musculus, abbreviated $\left.\mathrm{Ms}\right),{ }^{(149)}$ chicken (Gallus gallus, denoted Ch) ${ }^{(1,150,151)}$ and Xenopus laevis $(\mathrm{Xl}){ }^{(18)}$ Numbering is for the $\mathrm{hVDR}$ as published by Baker et al. ${ }^{(147)}$ Not shown are sequences from rat ${ }^{(148)}$ and Japanese quail, ${ }^{(151)}$ which are similar to the mouse and chicken, respectively. Alternative translation start sites for chicken $(\mathrm{Ch})$ or human $(\mathrm{Hu})$ mRNAs are indicated by arrows. The approximate location of residues corresponding to $\alpha$-helices $(h-A, h-1$, etc.) in the crystal structures of $\mathrm{hTR} \beta,^{\left({ }^{(102)}\right.} \mathrm{rTR} \alpha^{(119)}$ and hRAR $\gamma^{(118)}$ are indicated by brackets above the sequences. By similar analogy, ligand contacts in rTR $\alpha^{(119)}$ and hRAR $\gamma^{(118)}$ are indicated by solid triangles below the sequences if found in both crystal structures, or by open triangles if found in only one structure. Artificial point mutations in hVDR that inhibit transcriptional activity without affecting either $1,25(\mathrm{OH})_{2} \mathrm{D}_{3}$ binding or heterodimerization are denoted by solid circles under the sequences. An asterisk indicates the stop codon.

than the M1 VDR in a transient transfection assay employing a VDRE-linked reporter gene. ${ }^{(96)}$ We have independently observed that the M4 hVDR is significantly more effective than the longer M1 receptor in activating the transcription of VDRE-reporter constructs in several transfected mammalian cell lines, including osteoblasts (L. Remus and P. Jurutka, unpublished results). The conclusion that the M4 $(F)$ hVDR isoform is more transcriptionally potent is in concert with recent studies which suggest an association between the $F$ hVDR allele and enhanced BMD in two different populations. ${ }^{(96,97)}$ This raises the possibility that the $F$ neomorphic VDR allele, and speculatively the $L$ grouping of microsatellite variants (linked to varying degrees with $b / a / T$ alleles), may provide partial protection against osteoporosis by ensuring enhanced BMD via the increased activity of hVDR throughout life.

\section{Functional domains in the VDR protein}

As depicted schematically in Fig. 2(B) and conceptualized later in this review, VDR is a $1,25(\mathrm{OH})_{2} \mathrm{D}_{3}$-dependent transcription factor that controls gene expression by heterodimerizing with retinoid $\mathrm{X}$ receptors (RXRs) and associating specifically with VDREs in target genes. ${ }^{(99)}$ The principal functional domains of hVDR (Fig. 2B) that effect this action include those for hormonal ligand binding, heterodimerization, DNA binding/nuclear localization, and transcriptional activation. The lower portion of Fig. 2(B) also illustrates the 18 point mutations in VDR detected to date in HVDRR patients (reviewed in Refs. 10-13 and 100). Five of these genetic alterations result in nonsense $(\mathrm{X})$ or frameshift $(f)$ mutations that introduce premature stop codons in the receptor (R73X, E92f, ${ }^{(101)}$ Q152X, L233f, and Y295X), creating truncated VDRs that lack both hormone- and DNA-binding/heterodimerization capacities and are associated with unstable mRNAs. More revealing are the series of missense mutations (Fig. 2B) that can be classified according to three of the major molecular functions of VDR: DNA binding/nuclear localization by the $\mathrm{N}$-terminal zinc finger region (G33D through R80Q), 1,25$(\mathrm{OH})_{2} \mathrm{D}_{3}$ hormone binding by the C-terminal domain (R274L, H305Q, and I314S), and heterodimerization with RXRs through subregions of the C-terminal domain (I314S and R391C).

\section{DNA binding}

As with other nuclear receptors, all VDRs described to date possess a conserved DNA binding domain consisting of two zinc finger motifs (Fig. 2B and Fig. 3, residues 24-90 in hVDR). Although X-ray crystallographic data are not yet available for VDR, the solution of the cocrystal structure for the DNA binding domains of thyroid hormone receptor (TR)-RXR on a thyroid hormone responsive element $(\mathrm{TRE})^{(102)}$ provides an initial approximation of VDR structure/function in the DNA binding region. Accordingly, as detailed in Fig. 3, an $\alpha$-helix resides on the C-terminal side of each zinc finger, with helix A and helix B constituting the DNA-recognition and phosphate backbone binding helices, respectively. Among the naturally occurring missense mutations in this segment of hVDR (Fig. 2B), his-35, lys-45, arg-50, arg-73, and arg-80 all correspond to DNA contacts in the TR-RXR-TRE cocrystal. That these alterations cause the HVDRR phenotype of $1,25(\mathrm{OH})_{2} \mathrm{D}_{3}$ resistance in patients ${ }^{(10)}$ argues strongly for the existence of a reasonable structural congruity between the VDR finger region and that of TR.

As a further analogy with the TR-RXR cocrystal, ${ }^{(102)}$ the 
region just $\mathrm{C}$-terminal to the zinc fingers in VDR (Fig. 2B, residues 91-115 in hVDR), containing the T- and A-box helical region (denoted helices C/D in Fig. 3), likely also provides DNA contacts. The functional significance of putative helices A-D in DNA binding by VDR is emphasized by the near absolute conservation across species of the residues therein (Fig. 3). An interesting point concerning the VDR DNA binding domain is the presence, unique to VDRs, of a cluster of five basic amino acids in the intervening sequence between the two zinc fingers (Fig. 2B, $\oplus$; residues 49-55 in Fig. 3). Four of these positively charged residues (excluding lys-55) are hypothesized to make DNA contact based on the Rastinejad model, ${ }^{(102)}$ but this region is also crucial for nuclear localization of the receptor. ${ }^{(103)}$ In addition, this segment includes ser-51, a site of hVDR phosphorylation (Fig. 2B) by protein kinase $\mathrm{C}^{(104)}$ that results in inhibition of VDRE binding by phospho-VDR, in vitro. $^{(105)}$ Thus, phosphorylation of ser-51 could conceivably modulate both DNA-binding and nuclear localization of VDR, in vivo.

\section{Nuclear localization}

Biochemical fractionation and in situ immunocytochemical localization studies have shown that VDR is predominantly a nuclear protein, even in the unoccupied state. ${ }^{(106-110)}$ Two studies to date have examined potential nuclear localization domains in hVDR, ${ }^{(103,111)}$ focusing mainly on stretches of basic amino acids, such as those that have been implicated in nuclear localization of other steroid hormone receptors. ${ }^{(112-114)}$ The results of Luo et al. ${ }^{(111)}$ suggest that a bipartite signal consisting of a cluster of basic residues at each end of the sequence between amino acids 79 and 105 of hVDR is required for nuclear accumulation. Hsieh et al. ${ }^{(103)}$ have identified a separate basic sequence between the two zinc fingers of hVDR (residues 49-55) that represents a second nuclear localization signal. It remains unclear whether the identified three basic clusters of positively charged residues, which are absolutely conserved in helices A, B, and C (Fig. 3), function together or independently to effect nuclear translocation. The observations that point mutations causing HVDRR occur at arg-80(115) in the bipartite signal, and at $\arg -50^{(116)}$ in the second signal, and that neither mutated receptor is competent in transferring ligand to the nucleus, strongly suggest a necessity for both nuclear localization signals. Finally, as denoted in Fig. 2(B), the entire DNA binding domain, as a functional unit, may be required for optimal retention of VDR in the nucleus as a result of the general interaction of VDR with DNA. ${ }^{(115,117)}$

\section{Hormonal ligand binding}

Based upon the partial X-ray crystal structures of human retinoic acid receptor $\gamma(\mathrm{hRAR} \gamma),{ }^{(118)}$ rat $\mathrm{TR} \alpha_{1},{ }^{(119)}$ as well as unoccupied but homodimeric $\operatorname{hRXR} \alpha,{ }^{(120)}$ the ligand binding domain of nuclear receptors consists of a "sandwich" of $12 \alpha$-helices and several short $\beta$-strands organized in three dimensions around a lipophilic hormone-binding pocket. Following this analogy, three regions of hVDR in closest proximity to the $1,25(\mathrm{OH})_{2} \mathrm{D}_{3}$ ligand would extend approximately from residues 227-240, 268-316, and 396422 (Fig. 2B). As shown in Fig. 3, ligand contact sites at the individual amino acid level in the crystal structures of ligand-occupied hRAR $\gamma^{(118)}$ and agonist-occupied $\operatorname{rTR} \alpha_{1}{ }^{(119)}$ map to clusters in helix 3 , helix 5 , helix 11 , and helix 12 , as well as the $\beta$-strands (not delineated) that flank helix 6 . Several of the mutations characterized in hVDR that compromise ligand binding coincide with hormone contact sites in RAR and/or TR. These include the natural mutations $\mathrm{R} 274 \mathrm{~L}^{(121)}$ and H305Q, ${ }^{(13)}$ as well as artificial hVDR mutations at leu-233, ${ }^{(122)}$ cys-288, ${ }^{(123)}$ and his-397. ${ }^{(124)}$ The conclusion from these identified mutant hVDRs is that the structure of the VDR ligand binding domain, with the exception of relatively unconserved amino acids between residues 155 and 194 (exon V, see above and Fig. 3), closely resembles that of its nuclear receptor subfamily cousins, RAR and TR. A similar thesis has been presented independently by Wurtz et al., ${ }^{(125)}$ who modeled the hormone binding domain of liganded VDR utilizing coordinates from the X-ray crystal structure of holo-RAR $\gamma$.

\section{Heterodimerization with $R X R$}

From large deletion studies with VDR, Nishikawa and coworkers $^{(126)}$ determined that VDR dimerization surfaces are found in the first zinc finger, in a region just $\mathrm{C}$-terminal of finger-2, and in the large C-terminal ligand binding domain. Higher resolution mapping experiments have revealed that weak heterodimerization between VDR and RXR is facilitated by specific contact sites in the DNA binding domain of VDR (Fig. 2B). By site-directed mutagenesis, Hsieh et al. ${ }^{(127)}$ have shown that lys-91 and glu92, which are situated in the T-box region of hVDR (just C-terminal of finger-2 at the beginning of helix $\mathrm{C}$ in Fig. 3), mediate heterodimerization between the VDR and RXR DNA binding domains on the VDRE scaffold. This finding is independently supported by a modeling study, ${ }^{(102)}$ which also identifies Asn-37, located in the first zinc finger of hVDR, as an amino acid that contacts residues in the second zinc finger of the RXR partner in determining selective association of VDR with a VDRE consisting of a direct repeat spaced by three nucleotides (DR3). Within the hormone binding domain, two regions of hVDR that are involved in strong, ligand-dependent heterodimerization with RXR have been deduced by mutagenesis experiments and by analogy to the RXR homodimer crystal (Fig. 2B). ${ }^{(120)}$ These two subdomains consist of hVDR residues $244-263,{ }^{(100,128-130)}$ and amino acids 317-395, ${ }^{(124,130)}$ corresponding to portions of helices $3-4$ and $7-10$, respectively (Fig. 3). The helix $7-10$ region is positionally equivalent to contacts between $\mathrm{hRXR} \alpha$ residues in a homodimer as determined via X-ray crystallography by Bourguet et al. ${ }^{(120)}$ Thus, as illustrated in Figs. 2 and 3, the schematic picture of hVDR that is developing not only maintains the modular concept of receptor organization with general DNA and hormone binding domains, but also illuminates the complexity of regions within the ligand binding domain required for supporting both heterodimerization and hormone binding functions. The aforementioned I314S and 
R391C natural mutations (Fig. 2B) are unique because they provide evidence for a potential structural interplay between heterodimerization and hormone binding of VDR. I314S, which endows hVDR with combined defects in both hormone retention and heterodimerization, ${ }^{(11)}$ lies within helix-7, near a presumed juncture of ligand binding and heterodimerization subdomains of the receptor (Fig. 2B). Likewise, R391C is positioned within the helix-10 dimerization surface, but not far removed from $\mathrm{C}$-terminal ligand binding contacts (Figs. 2B and 3), consistent with the observed phenotype of a primary heterodimerization defect and a milder, secondary ligand retention deficiency. ${ }^{(11)}$ The conclusion is that the ligand binding and heterodimerization functions are interrelated within the context of the tertiary structure of VDR, likely via allosteric effects that ultimately generate an active receptor conformation.

\section{Transactivation}

The mechanism of transcriptional up-regulation employed by the agonist activated RXR-VDR heterodimer, once bound to DNA, is just now becoming understood. Functional evaluation of VDR points to at least two regions of the receptor required exclusively for transcriptional activation. One of these regions (residues 244-263) has already been noted for its role in heterodimerization (see above). However, embedded in this domain is lys-246 in hVDR (Fig. 3, denoted by a solid circle below the sequences), a residue not involved in heterodimerization, but whose alteration, even by conservative arginine replacement, severely compromises transactivation. ${ }^{(129)}$ A recent report has extended this observation to the estrogen receptor, ${ }^{(131)}$ and proposes, as did Whitfield et al., ${ }^{(129)}$ that this residue, which is highly conserved among nuclear receptors, forms part of the binding interface with transcriptional coactivators (see Fig. 4 and later discussion). The second region, by analogy with other nuclear receptors, is known as a liganddependent activation function or AF-2, and corresponds to helix 12 (Fig. 3) of the hormone binding domain. ${ }^{(132-135)}$ Analysis of this domain in hVDR by site-directed mutagenesis has identified leu-417 and glu-420 (also denoted by solid circles in Fig. 3) as pure, hormone-dependent transcriptional activation residues, with their alteration having little effect on either hormone binding or heterodimeric DNA binding. ${ }^{(136,137)}$ Like lys-246, leu-417 and especially glu-420 function to stimulate transcription by a mechanism involving coactivators. ${ }^{(136-138)}$

The transcriptional capacity of hVDR can be modulated in response to phosphorylation by kinases that participate in distinct signal transduction pathways. ${ }^{(139,140)}$ For example, hVDR is phosphorylated by protein kinase A (PKA), presumably in the central portion of the molecule between the DNA and hormone binding regions, resulting in an attenuation of $1,25(\mathrm{OH})_{2} \mathrm{D}_{3}$-activated transcription. ${ }^{(141,142)}$ In addition, hVDR is phosphorylated by casein kinase II (CK-II), in vitro, at ser-208, the major hormone-regulated phosphorylation site, in vivo (Fig. 2B). ${ }^{(143,144)}$ Overexpression of CK-II in mammalian cells effects a potentiation of $1,25(\mathrm{OH})_{2} \mathrm{D}_{3}$-stimulated transcription, ${ }^{(145)}$ indicating that the control of gene expression by $1,25(\mathrm{OH})_{2} \mathrm{D}_{3}-\mathrm{VDR}$ can be fine-tuned via phosphorylation, probably allowing for cross-talk between the VDR and other signal transduction pathways, and perhaps even governing receptor activity at different stages of the cell cycle or during cell differentiation. ${ }^{(139,146)}$

\section{Comparison of VDRs across species}

To date, VDR cDNAs have been cloned from six species, namely human, ${ }^{(147)}$ rat, ${ }^{(148)}$ mouse, ${ }^{(149)}$ chicken, ${ }^{(1,150,151)}$ Japanese quail, ${ }^{(151)}$ and frog (Xenopus laevis). ${ }^{(18)}$ As illustrated in Fig. 3, a direct comparison of the deduced amino acid sequences from four of these VDRs reveals significant sequence similarity. One variation that emerges from this comparison is that both avian VDRs (only the chicken sequence is shown) have a 22-residue $\mathrm{N}$-terminal extension that possesses two alternative translational start sites which are positionally $5^{\prime}$ of those in other VDRs. ${ }^{(150,151)}$ In contrast, a $3^{\prime}$ met- 4 is an alternative translational start site in the $f$ (M1) hVDR allele shown in Fig. 3. As detailed above in the human polymorphism section, in an apparently evolutionarily advantageous neomorph of hVDR ( $F$ or M4), the met- 1 codon is mutated to render alternative met- 4 the translational initiation site.

Major regions of hVDR display a striking degree of sequence similarity (Fig. 3), with the highest degree of conservation occurring in those domains of known functional significance. Prominent examples evident in Fig. 3 include the DNA-binding/nuclear localization domain (helices A-D), and the helix 3-12 ensemble that performs an intricate combination of $1,25(\mathrm{OH})_{2} \mathrm{D}_{3}$ binding, RXR heterodimerization and transactivation as discussed above. Encompassing most of the amino acids encoded in exon $\mathrm{V}$, there occurs a poorly conserved central region (approximately residues 159-201 in hVDR) between putative helices 1 and 3 of the hormone binding domain, which displays $47 \%$ identity between human and rat, $19 \%$ between human and Xenopus, and only $16 \%$ between human and chicken VDRs. Not surprisingly, this segment of VDR is also unique when compared with other nuclear receptors, a fact that prevents assignment of helix 2 in VDR based on structural data from TR, RAR, or RXR (Fig. 3). Nevertheless, the homology data in Fig. 3 provide compelling support for the current linear structure/function model of hVDR pictured in Fig. 2(B).

\section{MECHANISM WHEREBY THE VDR-RXR HETERODIMER MEDIATES THE ACTION OF $1,25(\mathrm{OH})_{2} \mathrm{D}_{3}$ TO CONTROL GENE TRANSCRIPTION}

\section{VDREs that mediate transactivation}

Sequence and promoter analyses of several 1,25$(\mathrm{OH})_{2} \mathrm{D}_{3}$-regulated genes have led to the identification of VDREs, short DNA sequences to which the VDR binds as a heterodimer with RXR and subsequently exerts its influence on transcription. The top portion of Table 2 lists those VDREs identified in genes that are known to be transcriptionally activated by the $1,25(\mathrm{OH})_{2} \mathrm{D}_{3}$ hormone, including 
Table 2. VDRE Sequences in VDR-Regulated Genes

\begin{tabular}{|c|c|c|c|c|c|}
\hline Gene & $\begin{array}{c}\text { Effect on } \\
\text { transcription* }\end{array}$ & \multicolumn{3}{|c|}{ Vitamin $D$ responsive element ${ }^{\dagger}$} & Reference(s) \\
\hline & & $\underline{5^{\prime}-\mathrm{RXR}}$ & & $\underline{3^{\prime}-V D R}$ & \\
\hline Rat osteocalcin & + & GGGTGA & ATG & AGGACA & $(155,233-235)$ \\
\hline Human osteocalcin & + & GGGTGA & ACG & GGGGCA & $(236-238)$ \\
\hline Mouse osteopontin & + & GGTTCA & CGA & GGTTCA & $(239)$ \\
\hline Avian $\beta_{3}$ integrin & + & GAGGCA & GAA & GGGAGA & $(240)$ \\
\hline Rat 24-OHase-proximal & + & AGGTGA & GTG & AGGGCG & $(33,241)$ \\
\hline Rat 24-OHase-distal & + & GGTTCA & GCG & GGTGCG & $(242)$ \\
\hline Mouse calbindin- $\mathrm{D}_{28 \mathrm{k}}$ & + & GGGGGA & TGT & GAGGAG & $(243)$ \\
\hline NPT2 & + & GGGGCA & GCA & AGGGCA & $(41)$ \\
\hline p21 (Cdk inhibitor) & + & AGGGAG & $\mathrm{ATT}$ & GGTTCA & $(228)$ \\
\hline \multirow[t]{2}{*}{ Random selection ${ }^{\ddagger}$} & + & PuGGTCA & NNG & PuGTTCA & $(152,153)$ \\
\hline & & VDR (RXR?) & & XR (VDR?) & \\
\hline Avian PTH & - & GGGTCA & GGA & GGGTGT & $(244)$ \\
\hline Human $\mathrm{PTH}^{\S}$ & - & GGTTCA & AAG & CAGACA & $(29,39)$ \\
\hline Mouse osteocalcin & - & GGGCAA & ATG & AGGACA & $(162)$ \\
\hline Rat bone sialoprotein & - & AGGGTT & $\underline{\text { TAT }}$ & AGGTCA & $(245)$ \\
\hline PKA inhibitor & - & ATGTTG & $\overline{\mathrm{CTG}}$ & $\overline{\mathbf{A}} \mathbf{G G T C A}$ & $(165)$ \\
\hline Rat PTHrP-proximal & - & AGGTTA & $\mathrm{CTC}$ & AGTGAA & $(246)$ \\
\hline Rat PTHrP-distal & - & GGGTGG & AGA & GGGGTG & $(247)$ \\
\hline
\end{tabular}

*VDREs activated by $1,25(\mathrm{OH})_{2} \mathrm{D}_{3}-$ VDR are shown in the upper portion and those repressed are listed in the lower portion.

'Bases depicted in darker type are those homologous to the randomly selected, highest affinity VDRE.

${ }^{\ddagger}$ Consensus VDRE determined by binding of VDR-RXR heterodimers to randomly synthesized oligonucleotide sequences; $\mathrm{Pu}=$ purine.

${ }^{\S}$ VDR heterodimerizes with a factor distinct from RXR on this VDRE.

"Antisense TATA box is underlined.

osteocalcin and osteopontin (expressed in bone osteoblasts), $\beta_{3}$ integrin (found in bone osteoclasts and macrophages), 24-OHase and NPT2 (discussed above), calbindin$\mathrm{D}_{28 \mathrm{k}}$ (from kidney) and p21 (an inhibitor of cyclindependent kinase [Cdk] in many tissues). In addition, two laboratories $^{(152,153)}$ have probed VDRE criteria by random selection of oligonucleotides that form complexes with VDR in combination with RXR (Table 2, center), providing results that are in general agreement with the natural VDREs. For positive transcriptional regulation, the VDRE is thus defined as a DR3, or direct repeat of two 6-base pair (bp) half elements that resemble estrogen-responsive element half-sites, separated by a spacer of three nucleotides. As depicted in Table 2 (top), VDR occupies the $3^{\prime}$ half-site of positive DR3 VDREs, while the 5' half-site is bound by the RXR heteropartner. ${ }^{(154)}$ Examination of both the natural and randomly selected VDRE sequences suggests that the $\mathrm{G}$ at position 3 of the spacer is important in VDR binding, a deduction consistent with the finding ${ }^{(155)}$ that in the rat osteocalcin motif this base is partially protected by RXR-VDR in methylation interference assays. With the exceptions of osteopontin and p21, numerous sequence variations are evident in the $3^{\prime}$ half-element of natural VDREs when they are compared with the PuGTTCA random consensus selection for this half-element (Table 2). This variability could be related to a need for VDREs of graded potency in regulated genes, or may even provide for a repertoire of different VDR conformations that could be induced by contact with distinct $3^{\prime}$ half-site core sequences. ${ }^{(156)}$ This postulated range of VDR conformations might endow the receptor with the ability to recruit a variety of different coactivators. Finally, the presence of two VDREs in the 24-OHase gene promoter (Table 2) intimates that the regulation of this enzyme is even more complex and may manifest hypersensitivity in order to effect the rapid elimination of the $1,25(\mathrm{OH})_{2} \mathrm{D}_{3}$ hormone. Irrespective of the above considerations, it is evident that the primary positive VDRE is a DR3 recognition site in DNA that attracts RXR-VDR to the promoter region of $1,25(\mathrm{OH})_{2} \mathrm{D}_{3}$-regulated genes, ultimately adjusting the functions of target cells as a result of transcriptional control of gene expression.

\section{VDREs that mediate transrepression}

Certain genes are negatively controlled at the level of transcription by the $1,25(\mathrm{OH})_{2} \mathrm{D}_{3}$ hormone, and this transrepression apparently occurs by several different mechanisms, including primary or secondary effects. For example, secondary effects involving the induction of intermediary proteins include $1,25(\mathrm{OH})_{2} \mathrm{D}_{3}$ suppression of c-myc expression (Table 1), ${ }^{(157,158)}$ and probably of atrial natriuretic peptide in cardiac myocytes (Table 1 and S. Chen et al., unpublished results). In what may be a primary effect, Alroy et al. ${ }^{(159)}$ report that VDR binds, in vitro, to the human 
Table 3. Effects of 9-Cis Retinoic Acid Ligand for RXR on Transactivation by the VDR-RXR Heterodimer

Antagonistic effects*

1. Blocking of $1,25(\mathrm{OH})_{2} \mathrm{D}_{3}$ antiproliferative action on HT-29 colon cancer cells; ${ }^{(170)}$ inhibition of $1,25(\mathrm{OH})_{2} \mathrm{D}_{3}$ stimulated chondrogenesis of chick limb bud mesenchymal cells ${ }^{(248)}$

2. Inhibition of $1,25(\mathrm{OH})_{2} \mathrm{D}_{3}$-induced osteocalcin mRNA accumulation in ROS 17/2.8 osteosarcoma cells ${ }^{(99)}$

3. Inhibition of $1,25(\mathrm{OH})_{2} \mathrm{D}_{3}$-mediated VDR-RXR binding to osteocalcin and osteopontin VDREs ${ }^{(99,249,250)}$

4. Suppression of $1,25(\mathrm{OH})_{2} \mathrm{D}_{3}$-elicited transactivation of a reporter gene from an osteocalcin or osteopontin-like VDRE in transfected cells ${ }^{(99,175)}$

Additive or synergistic effects*

1. Antiproliferative actions on the following cells in culture: human pancreatic carcinoma (Capan-1 and Capan-2), ${ }^{(169)}$ colon cancer (Caco-2), ${ }^{(170)}$ human promyelocytic leukemia (U937 and HL-60), ${ }^{(231,251-253)}$ prostate cancer $(\mathrm{LNCaP}){ }^{(173)}$ and breast cancer $(\mathrm{MCF}-7)^{(254)}$

2. Induction of 24-OHase mRNA in human skin ${ }^{(171)}$ and colon cancer cells $\left(\right.$ HT-29) ${ }^{(170)}$

3. None reported

4. Transactivation in transient transfections employing the following VDREs: synthetic perfect DR3s consisting of GGGTGA $^{(174)}$ and AGGTCA ${ }^{(174,255)}$ half elements, both rat 24-OHase VDREs, ${ }^{(256)}$ mouse osteopontin VDRE, ${ }^{(174)}$ human osteocalcin VDRE, ${ }^{(174)}$ and a putative inverted repeat VDRE in the calbindin-D ${ }_{9 k}$ gene $^{(257)}$

*1. Cell growth and differentiation; 2. mRNA accumulation; 3. VDR-RXR heterodimerization; 4. transactivation.

IL-2 promoter to prevent NFATp/AP-1 complexing with the DNA, thereby effecting transrepression. However, unlike the rat osteocalcin gene, where liganded VDR has been shown to associate with the positive VDRE via in vivo footprinting, ${ }^{(160)}$ no evidence has been provided that VDR directly binds to the IL-2 promoter in a ligand-dependent fashion, in vivo.

In other cases of transrepression by $1,25(\mathrm{OH})_{2} \mathrm{D}_{3}$, there also exist data that VDR binds to the promoter in question, in vitro, and does so in a heterocomplex with $\mathrm{RXR}$, or with another tissue-specific silencing coreceptor. For instance, VDR represses human PTH transcription in a 1,25$(\mathrm{OH})_{2} \mathrm{D}_{3}$-dependent manner by complexing with a coreceptor distinct from RXR, ${ }^{(29)}$ but on an element that resembles a degenerate DR3 VDRE with substitutions in the $3^{\prime}$ halfelement (Table 2, lower portion). The putative avian PTH negative VDRE is also similar to the consensus positive VDRE, except that the $G$ in the spacer and the last two bases (CA) in the $3^{\prime}$-half element are replaced by other nucleotides (Table 2). Interestingly, when Russell and coworkers $^{(161)}$ altered the two 3' terminal bases (GT) back to the consensus CA, the avian PTH VDRE reverted from a negative to a positive VDRE. Moreover, the mouse osteocalcin VDRE, which unlike the rat and human osteocalcin VDREs confers negative control by $1,25(\mathrm{OH})_{2} \mathrm{D}_{3},{ }^{(162)}$ also possesses only two base differences (positions 4 and 5 of the 5 ' half-element) from that of the rat sequence (Table 2). A separate secondary mechanism for negative osteocalcin control by $1,25(\mathrm{OH})_{2} \mathrm{D}_{3}$ in the mouse appears to involve suppression of an osteoblast-specific activator that binds to a cis-acting element in the promoter. ${ }^{(163)}$ Nevertheless, based upon observations with VDREs in the avian PTH gene as well as mouse versus rat osteocalcin, simply changing $2 \mathrm{bp}$ in either half-element of a VDRE reverses the direction of transcriptional regulation by $1,25(\mathrm{OH})_{2} \mathrm{D}_{3}$ as mediated by the VDR. How is this on-off switch accomplished mechanistically? One possibility is that the polarity of the RXR-VDR heterocomplex on the VDRE is altered such that the VDR occupies the 5' half-element when gene control is negative. ${ }^{(161)}$ There is, in fact, precedent for binding orientation reversal conferring negative regulation in the case of the RAR-RXR heterocomplexes. ${ }^{(164)}$ Another possibility is that base pair substitutions in either half-element conform the VDR complex such that it cannot recruit a coactivator, or perhaps retains a corepressor. The concept of VDRE association altering the tertiary structure of VDR is supported by the observation that a 2 bp change of TT to GA in positions 3 and 4 of the $3^{\prime}$ half-element, as in the mouse osteopontin versus rat osteocalcin VDREs, appears to alter the conformation of VDR as judged by antibody epitope accessibility and protease sensitivity. ${ }^{(156)}$ Either or both of the potential mechanisms of reverse VDR/RXR orientation or negative VDR conformation could come into play in primary transrepression. Yet a third mechanism involving occlusion of an active site in the promoter apparently occurs with the bone sialoprotein gene upstream region, wherein the RXR-VDR or VDR-RXR complex binds to a VDRE overlapping an inverted TATA box (Table 2), presumably occluding TATA-binding protein association. A similar situation may occur in the case of the PKA inhibitor gene (Table 2), in which a putative negative VDRE is situated between two TATA sequences. ${ }^{(165)}$ However, more research is clearly needed before we will have a comprehensive understanding of negative transcriptional regulation by VDR.

\section{The effect of 9-cis retinoic acid, the ligand for $R X R$, on VDR signaling}

An additional level of control of the VDR-RXR heterodimer could conceivably be exerted by RXR ligands, primarily the natural 9-cis retinoic acid (9-cis RA) hormone. ${ }^{(99)}$ Precedents from other receptors that heterodimerize with RXR encompass a spectrum of effects. With respect to transactivation by all-trans RA as mediated by the RXR-RAR heterodimer, subsequent addition of RXR-specific ligands, referred to as rexinoids, further aug- 
Table 4. Interaction of VDREs with Nearby or Overlapping Cis Elements That Bind Regulatory Proteins

\begin{tabular}{|c|c|c|c|c|}
\hline Gene & VDRE-type & Cis-trans modifier & $\begin{array}{c}\text { Effect on } \\
\text { transcription }\end{array}$ & Reference \\
\hline Rat osteocalcin & DR3 & $\begin{array}{l}\text { Inhibitory YY1 competes with VDR/RXR } \\
\text { by overlapping the VDRE }\end{array}$ & - & $(177)$ \\
\hline Human osteocalcin & DR3 & Upstream AP-1/fos-jun & + & $(238)$ \\
\hline Rat osteocalcin & DR3 & $\begin{array}{l}\text { Downstream ligand-dependent } \\
\text { transcription sequence (GGTTTGG) }\end{array}$ & + & (258) \\
\hline Mouse calbindin- $\mathrm{D}_{28 \mathrm{k}}$ & weak DR3 & Adjacent butyrate responsive element & + & $(243)$ \\
\hline Rat 24-OHase & $\begin{array}{l}\text { coordinate } \\
\quad \text { (two DR3s) }\end{array}$ & $\begin{array}{l}\text { Ligand-dependent transcription sequence } \\
\text { (AP-2-like) adjacent to proximal DR3 }\end{array}$ & + & $(259)$ \\
\hline Mouse c-fos & composite & $\begin{array}{l}\text { CAAT-binding transcription factor binds } \\
\text { along with VDR and RXR }\end{array}$ & + & $(179)$ \\
\hline
\end{tabular}

ments gene activation from a retinoic acid response element. ${ }^{(166-168)}$ Conversely, the occupation of TR by thyroid hormone in an RXR-TR heterodimer silences the ability of that complex to bind and respond to 9-cis RA in terms of transactivation of a TRE-reporter construct. ${ }^{(166)}$ Studies with VDR have variously indicated antagonistic, additive, or synergistic effects of 9-cis RA in combination with $1,25(\mathrm{OH})_{2} \mathrm{D}_{3}$ (Table 3). In an attempt to reconcile these conflicting data, it is important to realize that these studies tend to assess four distinct endpoints: growth and differentiation of intact cells, accumulation of specific mRNAs, gel mobility shift assays of the heterocomplex binding to a VDRE, and transactivation from VDRE-reporter constructs in cotransfected cells. When the current body of data is considered, in toto, only the antagonistic effect of 9-cis RA on $1,25(\mathrm{OH})_{2} \mathrm{D}_{3}$ action is demonstrable at all four of the above levels (Table 3). Rat osteocalcin control is a prominent example in which 9-cis RA attenuates the ability of $1,25(\mathrm{OH})_{2} \mathrm{D}_{3}$ to elicit mRNA accumulation, heterodimeric VDRE binding, and transcription from a VDRE-reporter construct. Antagonism by 9-cis RA in the rat osteocalcin system may involve a simple RXR diversionary mechanism under conditions of high local levels of 9-cis RA and limiting RXR concentrations (see Fig. 4 below).

Positive effects of 9-cis RA on the action of $1,25(\mathrm{OH})_{2} \mathrm{D}_{3}$ appear to be a more complex, though seemingly widespread phenomenon (Table 3), perhaps occurring at multiple steps in cell and gene regulation. For example, as listed in Table 3, the combination of 9-cis RA and $1,25(\mathrm{OH})_{2} \mathrm{D}_{3}$ exerts additive growth inhibitory effects in select whole cell systems such as human pancreatic carcinoma (Capan) cells $^{(169)}$ and colon carcinoma (Caco-2) cells. ${ }^{(170)}$ Synergistic actions of $1,25(\mathrm{OH})_{2} \mathrm{D}_{3}$ and 9-cis RA have been noted mainly in cell growth and differentiation systems, in which a marked antiproliferative effect occurs in the presence of both ligands (Table 3). In addition, 24-OHase mRNA is synergistically enhanced in its accumulation when both ligands are present in two different cell systems. ${ }^{(170,171)}$ However, in no case has 9-cis RA been shown to increase (directly) $1,25(\mathrm{OH})_{2} \mathrm{D}_{3}$-mediated binding of VDR-RXR heterodimers to VDREs (Table 3). Furthermore, there is no definitive proof in many of these systems that the positive effect of 9-cis RA involves exclusively RXR-VDR het- erodimeric action on VDREs. For instance, 9-cis RA binds to RAR as well as RXR, raising the possibility that actions of this pan-ligand for retinoid receptors could transpire via the RXR-RAR heterodimer, although two of the relevant investigations $^{(172,173)}$ demonstrating synergism utilized RXR-specific (rexinoid) ligands, obviating any binding to RAR.

Synergistic activation of transcription linked to selected natural and synthetic VDREs also has been reported when transfected cells are exposed to both 9-cis RA and 1,25$(\mathrm{OH})_{2} \mathrm{D}_{3}$ (Table 3), including results with the osteopontin VDRE $^{(174)}$ that conflict with those of Lemon and Freed$\operatorname{man}^{(175)}$ who reported antagonism (Table 3). Caveats to these VDRE experiments are that the transient transfection studies often involved synthetic VDREs lacking natural flanking regions, overexpression of both partner receptors well beyond physiologic concentrations, or the use of heterologous cell systems. In genes whose $1,25(\mathrm{OH})_{2} \mathrm{D}_{3}$-induced expression is truly amplified by 9-cis RA and RXRspecific ligands, conceivable mechanisms could involve unique VDRE or flanking cis-element effects on the conformation of the RXR partner in the heterodimer such that it is receptive to the binding of rexinoids as agonists (see Fig. 4 and the next section).

The dual 24-OHase VDREs (Table 2) are again of particular interest in that, in contrast to the single rat osteocalcin VDRE, this VDRE pair confers synergistic activation by 9 -cis RA and $1,25(\mathrm{OH})_{2} \mathrm{D}_{3}$, both from a reporter construct and in the setting of the endogenous gene (Table 3 ). Other results ${ }^{(176)}$ indicate that 9-cis RA alone can positively influence 24-OHase gene transcription, rendering the RXR ligand a regulator of vitamin $\mathrm{D}$ metabolite catabolism. Therefore, 9-cis RA could achieve an effective biological suppression of bone remodeling by blunting the positive action of $1,25(\mathrm{OH})_{2} \mathrm{D}_{3}$ on osteocalcin transcription and by independently inducing the 24-OHase enzyme that in turn initiates the destruction of the $1,25(\mathrm{OH})_{2} \mathrm{D}_{3}$ hormone (Table 3). Future research will be needed to clarify the mechanisms by which 9-cis RA influences $1,25(\mathrm{OH})_{2} \mathrm{D}_{3}-$ VDR signaling, and also to explain the largely unknown effects of 9-cis RA on VDR-RXR heterodimers that bind to negative VDREs. 
Table 5. Candidate VDR-Interacting-Proteins (VIPs)

\begin{tabular}{lcll}
\hline \multicolumn{1}{c}{ VIP } & $\begin{array}{c}\text { Ligand } \\
\text { dependency }\end{array}$ & \multicolumn{1}{c}{ Proposed function of protein or complex } & Reference $(s)$ \\
\hline Calreticulin & - & inhibitor of DNA binding & $(260,261)$ \\
ERC-55 & - & calcium binding protein & $(262)$ \\
SMRT & + & corepressor & $(263)$ \\
RXR & + & active partner in DNA binding and transactivation & $(99,264)$ \\
SRC-1 (ACTR, TIF2, & + & coactivator, histone acetylation & $(137,265,266)$ \\
$\quad$ GRIP1, ERAP160) & & & $(267)$ \\
NCoA-62 & - & coactivator & $(268)$ \\
p65 & + & coactivator & $(269)$ \\
TIF1 & + & chromatin remodeling & $(270)$ \\
TAFII28 & + & TBP-associated factor & $(177,264,271,272)$ \\
TFIIB & \pm & basal transcription factor & $(186,187)$ \\
SUG1 & + & receptor degradation & $(187)$ \\
\hline
\end{tabular}

*Synonyms are listed in parenthesis

\section{Role of DNA sequences flanking or overlapping VDREs in positive VDR signaling}

Beyond the various agonist/antagonist effects of the two receptor ligands and sequence variation within the DR3 VDRE, additional regulatory influences could be exerted by other cis-elements within the promoter region that bind generic or tissue-specific transmodulators. The simplest mechanism for such cis-elements to affect VDR-mediated transcription is to overlap the VDRE, analogous in theory to the bone sialoprotein negative VDRE (discussed above) that possesses an intrinsic TATA box sequence. In fact, such overlap occurs when the trans-repressor $\mathrm{YY}^{(177)}$ binds to the rat osteocalcin VDRE region during the early stages of osteoblast differentiation to prevent VDR action (Table 4). More commonly, adjacent cis-elements and their associated transfactors appear to positively modulate transcriptional activation by the VDR-RXR heterocomplex. ${ }^{(178)}$ Specifically, $1,25(\mathrm{OH})_{2} \mathrm{D}_{3}$-stimulated transcription from human and rat osteocalcin promoters is further augmented by the involvement of an upstream AP1, or a downstream GGTTTGG sequence, respectively (Table 4). Also, calbindin- $\mathrm{D}_{28 \mathrm{k}}$, which is only modestly activated by $1,25(\mathrm{OH})_{2} \mathrm{D}_{3}$ at the transcriptional level, possesses an adjacent butyrate responsive element (Table 4) that supplements the effect of the hormone. A more complex situation exists in the aforementioned case of 24-OHase transcription, where the two VDREs (Table 2), approximately 100 bp apart in the promoter, plus the cooperation of the proximal VDRE with an adjacent AP-2-like sequence, are all required for full transcriptional activation (Table 4). Another mechanism discovered for cis-trans modification of a VDR-RXR bioeffect is the transient expression of the c-fos gene. ${ }^{(179)}$ This gene contains a composite VDRE distinct from a simple DR3, on which a bone cell-specific member of the CTF/NF-1 family of CAAT-box binding proteins forms an activating trimeric complex with VDR and RXR (Table 4). The examples discussed above indicate that there is potential for other signal transduction pathways to impinge on VDR function, and such cross-talk could be relevant in terms of the tissue and promoter selectivity of $1,25(\mathrm{OH})_{2} \mathrm{D}_{3}$ action. As target gene parameters are more carefully dissected, additional examples of such regulatory complexity will likely emerge.

\section{Integration of VDR interacting proteins into a model for transcriptional control by $1,25(\mathrm{OH})_{2} \mathrm{D}_{3}$}

To function as a ligand-dependent transcription factor, VDR must interact with a number of regulatory and signal transducing proteins (Table 5). The binding of VDR to DNA may be negatively controlled through association with calreticulin, a calcium-binding macromolecule capable of sequestering members of the nuclear receptor superfamily by contacting and masking the DNA recognition helix within the zinc finger region. ${ }^{(180)}$ It has been proposed that calreticulin association with VDR might somehow coordinate $1,25(\mathrm{OH})_{2} \mathrm{D}_{3}$ action with the calcium status of the cell (reviewed in Ref. 180). In addition to calreticulin, another putative calcium binding protein that interacts with VDR is ERC-55 (Table 5), although a functional role for this protein-protein contact has not yet been defined.

Unliganded VDR in the nucleus is likely bound to a corepressor related to the silencing mediator for retinoid and thyroid hormone receptors (SM $\bar{M}$ T) (Table 5 and Fig. 4). ${ }^{(181)}$ It is proposed that, analogous to closely related receptors such as RAR, ${ }^{(182)}$ the VDR-SMRT/corepressor complex is linked to histone deacetylase(s) that maintains chromatin in a repressed state with respect to transcription. As shown in Fig. 4, unliganded VDR is also envisioned to be weakly heterodimerized with RXR, and this multimer is postulated to be loosely and nonspecifically associated with DNA, perhaps sliding along the nucleic acid phosphate backbone. Upon VDR occupation by $1,25(\mathrm{OH})_{2} \mathrm{D}_{3}$, the receptor undergoes a dramatic conformational change, resulting in the following events which are illustrated in Fig. 4: dissociation of the corepressor; repositioning of the VDR AF-2 to the stimulatory, closed configuration; stabilization of the active conformation of VDR by phosphorylation; 


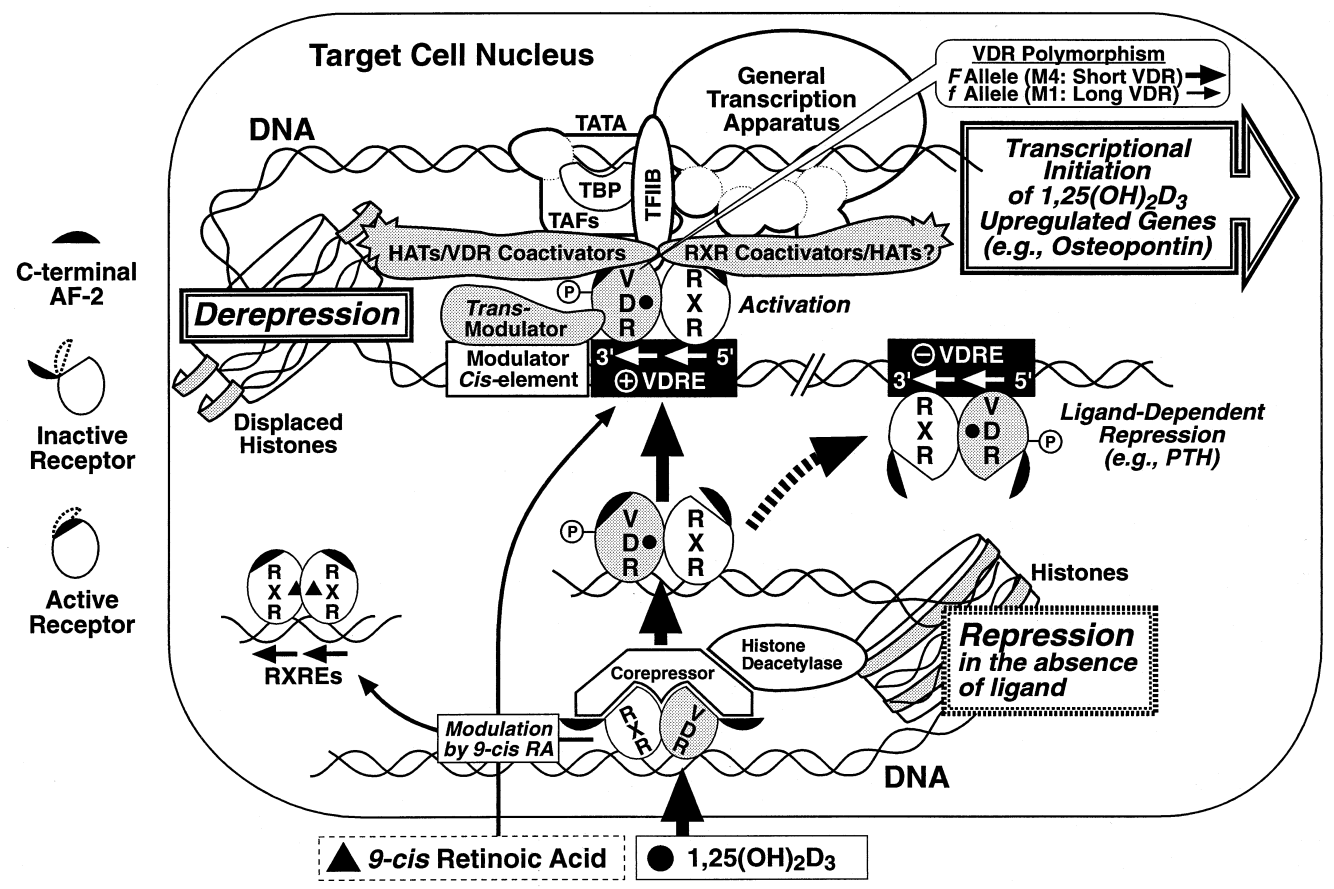

FIG. 4. Working model for transcriptional control by $1,25(\mathrm{OH})_{2} \mathrm{D}_{3}$. (Bottom) Unliganded VDR binds weakly to RXR and DNA and may also bind to a putative corepressor that promotes silencing of gene expression via recruiting histone deacetylase activity. Histone deacetylase maintains histones such that they promote a repressive nucleosome configuration in chromatin. Heavy solid arrows denote the proposed major pathway in which $1,25(\mathrm{OH})_{2} \mathrm{D}_{3}(\mathrm{O})$ enters the nucleus, binds VDR, and leads to high affinity association of the active $1,25(\mathrm{OH})_{2} \mathrm{D}_{3}-\mathrm{VDR}-\mathrm{RXR}$ complex with specific VDREs in the promoter regions of target genes. (Center and top) Liganded hVDR is transformed into an active conformation, with the AF-2 in the closed position (see legend at left), and also becomes phosphorylated on serine-208 in a $1,25(\mathrm{OH})_{2} \mathrm{D}_{3}$ dependent reaction, which potentiates transactivation by VDR. There is a high affinity interaction of $1,25(\mathrm{OH})_{2} \mathrm{D}_{3}-$ occupied VDR with RXR, which is postulated to influence the structure of RXR by bringing its AF-2 into the active orientation. In this model, positive VDRE binding by the activated heterodimer, with VDR positioned on the 3' half-element, leads to transcriptional derepression/stimulation of target genes via a combination of the following events: attraction of VDR coactivators that mediate derepression of chromatin nucleosome organization via histone acetyl transferase (HAT) catalyzed displacement of histones to unveil DNA, contact of VDR coactivators with TAF-TBP complex on the TATA box, and direct association of VDR with elements of the basal transcription machinery, such as TFIIB, to stabilize the preinitiation complex. Whether RXR also enlists coactivators that possess HAT activity and/or contact the general transcription apparatus has not been demonstrated, although the AF-2 of RXR in the heteropartner is absolutely required for transcriptional activation. ${ }^{(273)}$ Conversely, as indicated with a heavy broken arrow, binding of the VDR-RXR heterodimer to negative VDREs may place VDR on the 5' half-element, constituting one mechanism for ligand-dependent repression of target genes by interfering with transcription in an undefined way, perhaps by VDR-RXR existing in a conformation retaining corepressors or incapable of recruiting coactivators. (Top right) Polymorphic $(F$ versus $f$ ) forms of VDR are shown to modify transcriptional activity, in vivo, as a result of differences in VDR potency (within the multimeric complex) between the short (M4) and long (M1) proteins encoded by these alleles. (Lower left) Modulation by 9 -cis RA of $1,25(\mathrm{OH})_{2} \mathrm{D}_{3}$-stimulated transactivation apparently occurs by either of two pathways. Antagonism ensues when RXR is diverted away as a liganded homodimer to its own target, RXRE-containing genes, in the presence of high local concentrations of 9-cis retinoic acid ( $\mathbf{\Delta})$. Alternatively, binding of 9-cis RA to the $1,25(\mathrm{OH})_{2} \mathrm{D}_{3}$-occupied, DNAbound heterodimer may be directed by distinct VDREs and/or modulatory cis-elements, resulting in an additive or synergistic effect of these two ligands on transcription.

high affinity heterodimerization with RXR (Table 5), with a concomitant allosteric effect to configure the AF-2 of RXR into an active conformation; and specific recognition and tight association with the VDRE. As discussed earlier in this review, DR3 VDREs can be either positive or negative in their influence on gene transcription (Table 2). In the simplest mechanism (Fig. 4), positive VDREs like that in the mouse osteopontin gene bind the heterodimer with VDR situated on the $3^{\prime}$ half-element. Conversely, negative
VDREs such as in the avian PTH gene may be determined by a reverse orientation of binding, with VDR residing on the 5' half-element. However, as discussed above, a more intricate mechanism for establishing positive or negative regulation by $1,25(\mathrm{OH})_{2} \mathrm{D}_{3}$ could involve specific base pairs in either VDRE half-element dictating various receptor conformations that in turn are manifest as either transactivation or transrepression. As already outlined in Tables 3 and 4, and depicted in Fig. 4, the cis-environment of the 
VDRE and associated transmodulators may be able to control both the 9-cis RA/rexinoid receptivity and magnitude of the $1,25(\mathrm{OH})_{2} \mathrm{D}_{3}$ response, perhaps also governing promoter and cell selectivity, as well as allowing for crosstalk with other signal transduction pathways.

An exciting development in the action of nuclear receptors has been the recent isolation of coactivators, ${ }^{(182,183)}$ most of which appear to interact with the AF-2 domain. Coactivator interactions with VDR are currently being investigated, and an association has been demonstrated with ligand-dependent coactivators such as SRC-1, as well as with ligand-independent coactivators like NCoA-62 (Table 5 and references therein; note the synonyms for SRC-1). Beyond performing a crucial bridging function to the general transcription apparatus, coactivators are now thought to enzymatically modify histones in the nucleosomes in order to liberate DNA for transcription. This step is catalyzed by histone acetyl transferases (HATs), which possess the newly recognized feature of facilitating transcriptional activation. ${ }^{(184)}$ SRC-1 apparently possesses HAT activity, but supplemental HAT proteins like CBP and $\mathrm{P} / \mathrm{CAF},{ }^{(182)}$ as well as TIF1 (Table 5), also may be recruited to a supercomplex (Fig. 4) that both derepresses the promoter chromatin organization of the regulated target gene and links to the general transcription apparatus. In the case of the VDR-RXR heterocomplex, the primary receptor also appears to attract basal transcription factors like $\mathrm{TAF}_{\mathrm{II}} 28$ and TFIIB (Table 5). Therefore, we hypothesize that by combining the bridging effects of coactivators and of VDR, activation is targeted to the appropriate site of transcriptional initiation, with subsequent recruiting of TFIIB to trigger preinitiation complex assembly. In humans, this action of VDR is seemingly more efficient with the M4 $(F)$ neomorphic variant than with the longer M1 $(f)$ receptor (Fig. 4, see VDR polymorphism section above), implying that VDR alleles could be involved in the determination of BMD.

Although little is known about the termination of the $1,25(\mathrm{OH})_{2} \mathrm{D}_{3}-$ VDR signal beyond 24-OHase catalyzed catabolism of the ligand, interaction of activated VDR with SUG1 (Table 5; not shown in Fig. 4 for simplicity) likely targets the receptor for ubiquitination and subsequent proteolysis by the $26 \mathrm{~S}$ proteasome complex. ${ }^{(185-187)}$

The availability of a cell-free transcription system in which VDR-RXR heterodimers activate transcription in a $1,25(\mathrm{OH})_{2} \mathrm{D}_{3}$-dependent fashion ${ }^{(188)}$ should facilitate studies of transcriptional control by VDR, such as demonstrating direct effects by coactivators, promoter-specific factors, or corepressors. Ultimately, with such cell-free transcription systems it may also be feasible to incorporate elements of chromatin structure such as the aforementioned histones, in order to develop a system that truly mimics VDR action in vivo while at the same time permitting manipulations, in vitro.

\section{Recent mechanistically relevant observations on $1 \alpha, 25(\mathrm{OH})_{2} \mathrm{D}_{3}$ analogs}

Because of the magnitude of vitamin D analogs that have been synthesized, comprehensive coverage in this review is not feasible, and the reader is therefore referred to excellent treatises on this topic ${ }^{(189,190)}$ for a more detailed discussion. Nevertheless, the model in Fig. 4 suggests numerous facets that may differ between particular target genes and could therefore present opportunities for differential manipulation of bioeffects via $1,25(\mathrm{OH})_{2} \mathrm{D}_{3}$ and/or 9-cis RA analogs. Indeed, some success has already been reported with this type of approach. Certain $1,25(\mathrm{OH})_{2} \mathrm{D}_{3}$ side-chain analogs, such as 20 -epimerized derivatives, raise calcium levels in the intact organism only slightly more than the $1,25(\mathrm{OH})_{2} \mathrm{D}_{3}$ parent compound while at the same time stimulating transcription of VDRE-reporter constructs 1000 -fold more effectively, ${ }^{(191)}$ whereas other analogs, such as 22-oxa ${ }^{(192,193)}$ or 16-ene ${ }^{(194)}$ derivatives, exhibit sharply reduced calcemic activity but retain the ability to inhibit proliferation and induce cell differentiation. One analog in the latter general class, calcipotriol, is already employed in the treatment of psoriasis. ${ }^{(195)}$ The advent of noncalcemic derivatives allows for the desired antiproliferative or other tissue-specific actions of $1,25(\mathrm{OH})_{2} \mathrm{D}_{3}$ without creating unwanted hypercalcemia as a toxic side-effect. A recent report can serve as an example of what the future may hold. A 24-ethyl derivative of $1 \alpha(\mathrm{OH}) \mathrm{D}_{3}$, namely $1 \alpha(\mathrm{OH}) \mathrm{D}_{5}$, was shown to be a potent, nontoxic inhibitor of the proliferation of precancerous mammary lesions, in vivo, ${ }^{(196)}$ suggesting that $1,25(\mathrm{OH})_{2} \mathrm{D}_{3}$ derivatives may be used in cancer prevention as well as treatment.

The exact mechanistic basis for the unique effects of synthetic VDR ligands has not been elucidated, but there are indications that specific analogs can differentially affect ligand occupancy rates ${ }^{(191,197)}$ or VDR conformational states that may elicit distinct interactions with comodulators. ${ }^{(198)}$ For example, 20-epi analogs stabilize the receptor, ${ }^{(197)}$ presumably by binding deeper than $1,25(\mathrm{OH})_{2} \mathrm{D}_{3}$ in the ligand pocket, thereby slowing ligand dissociation and creating unique VDR (AF-2) conformational states that are superactive transcriptionally. ${ }^{(198)}$ Heterodimerization between VDR and RXR and resultant DNA binding is also differentially influenced by $20-$ epi $^{(191)}$ and $16-$ ene $^{(194)}$ analogs. Finally, utilizing the yeast two-hybrid assay, it has been shown that ligand-enhanced VDR-RXR heterodimerization correlates with transcriptional activation by a series of $1,25(\mathrm{OH})_{2} \mathrm{D}_{3}$ analogs. ${ }^{(199)}$ The current challenge is to elucidate further the VDR-related events initiated by superactive and bioselective $1,25(\mathrm{OH})_{2} \mathrm{D}_{3}$ analogs and to correlate these phenomena with pharmacologic profiles such that their molecular mode of action is understood.

\section{SUMMARY AND PROSPECTIVE DEVELOPMENTS}

The actions of $1,25(\mathrm{OH})_{2} \mathrm{D}_{3}-\mathrm{VDR}$ that have emerged from recent studies include, but clearly transcend, the bone and calcium/phosphate homeostasis effects originally attributed to vitamin D. This new understanding now encompasses many of the tissues formerly reported to contain vitamin D receptors, but for which no function of the vitamin-derived hormone could be ascribed. The insights gained from VDR knockout and allelic variation research 
confirm and extend these concepts, raising the prospect that, for the purpose of preventive measures, assessment of VDR polymorphisms may ultimately become part of a strategy to better identify and treat persons at risk for common disorders such as osteoporosis, breast cancer, or prostate cancer. We have learned much about VDR structure/function from natural mutations in 1,25$(\mathrm{OH})_{2} \mathrm{D}_{3}$-resistant patients and from site-directed mutagenesis experiments, as well as gained insight from the elucidation of analogous crystal structures for RAR, RXR, and TR. The next few years will no doubt witness a growing structural understanding of VDR, presumably culminating in the crystallographic resolution of physical details of liganded versus unliganded forms of VDR, perhaps in the absence and presence of various protein partners and/or VDRE binding sites. Such structural information should allow for the design of the next generation of synthetic analogs possessing the potential capability of selectively controlling individual $1,25(\mathrm{OH})_{2} \mathrm{D}_{3}$ responses within the organism.

Fundamental investigations also have led to an enhanced appreciation of the sequence of events in nuclear VDR signal transduction, offering promise that we may be able to understand how diverse $1,25(\mathrm{OH})_{2} \mathrm{D}_{3}$ agonists could differentially manipulate these steps in a promoter and/or tissue-specific fashion. Such analogs would therefore be endowed with therapeutic potential not only for classic VDR actions in calcium/phosphate homeostasis and bone mineralization, but also for hyperproliferative skin disorders and various types of cancer. A novel type of analog that will be useful in studies of VDR action is an authentic receptor antagonist, and preliminary reports ${ }^{(200,201)}$ indicate that this reagent may be available soon. Another new frontier of VDR function at the molecular level is clearly that of characterizing VDRinteracting proteins, and identifying how they mediate $1,25(\mathrm{OH})_{2} \mathrm{D}_{3}$ signaling within the context of specific gene promoters. These biochemical and genetic investigations may reveal mechanisms for potential interactions of $1,25(\mathrm{OH})_{2} \mathrm{D}_{3}$ with signaling pathways for other hormones, growth factors, and cytokines that physiologically modulate the wide array of vitamin D bioeffects.

\section{ACKNOWLEDGMENTS}

The research performed in our laboratory and cited in this review was supported by National Institutes of Health grants to M.R.H., G.K.W., and J.-C.H.

\section{REFERENCES}

1. McDonnell DP, Mangelsdorf DJ, Pike JW, Haussler MR, O'Malley BW 1987 Molecular cloning of complementary DNA encoding the avian receptor for vitamin D. Science 235:1214-1217.

2. Haussler MR, Mangelsdorf DJ, Komm BS, Terpening CM, Yamaoka K, Allegretto EA, Baker AR, Shine J, McDonnell DP, Hughes M, Weigel NL, O'Malley BW, Pike JW 1988 Molecular biology of the vitamin D hormone. Recent Prog Horm Res 44:263-305.
3. Evans RM 1988 The steroid and thyroid hormone receptor superfamily. Science 240:889-895.

4. Holick MF 1996 Vitamin D and bone health. J Nutr 126: 1159S-1164S.

5. MacDonald PN, Dowd DR, Haussler MR 1994 New insight into the structure and functions of the vitamin $\mathrm{D}$ receptor. Sem Nephrol 14:101-118.

6. Haussler MR, McCain TA 1977 Basic and clinical concepts related to vitamin D metabolism and action. N Engl J Med 297:974-983, 1041-1050.

7. Labuda M, Fujiwara TM, Ross MV, Morgan K, Garcia-Heras J, Ledbetter DH, Hughes MR, Glorieux FH 1992 Two hereditary defects related to vitamin D metabolism map to the same region of human chromosome 12q13-14. J Bone Miner Res 7:1447-1453.

8. St-Arnaud R, Messerlian S, Moir JM, Omdahl JL, Glorieux FH 1997 The 25-hydroxyvitamin D 1-alpha-hydroxylase gene maps to the pseudovitamin D-deficiency rickets (PDDR) disease locus. J Bone Miner Res 12:1552-1559.

9. Takeyama K, Kitanaka S, Sato T, Kobori M, Yanagisawa J, Kato S 1997 25-hydroxyvitamin $\mathrm{D}_{3}$ 1alpha-hydroxylase and vitamin D synthesis. Science 277:1827-1830.

10. Rut AR, Hewison M, Kristjansson K, Luisi B, Hughes MR, O'Riordan JLH 1994 Two mutations causing vitamin D resistant rickets: Modelling on the basis of steroid hormone receptor DNA-binding domain crystal structures. Clin Endocrinol 41:581-590.

11. Whitfield GK, Selznick SH, Haussler CA, Hsieh J-C, Galligan MA, Jurutka PW, Thompson PD, Lee SM, Zerwekh JE, Haussler MR 1996 Vitamin D receptors from patients with resistance to 1,25 -dihydroxyvitamin $\mathrm{D}_{3}$ : Point mutations confer reduced transactivation in response to ligand and impaired interaction with the retinoid $\mathrm{X}$ receptor heterodimeric partner. Mol Endocrinol 10:1617-1631.

12. Haussler MR, Haussler CA, Jurutka PW, Thompson PD, Hsieh J-C, Remus LS, Selznick SH, Whitfield GK 1997 The vitamin D hormone and its nuclear receptor: Molecular actions and disease states. J Endocrinol 154:S57-S73.

13. Malloy P, Eccleshall T, Gross C, Van Maldergem L, Bouillon R, Feldman D 1997 Hereditary vitamin D resistant rickets caused by a novel mutation in the vitamin $\mathrm{D}$ receptor that results in decreased affinity for hormone and cellular hyporesponsiveness. J Clin Invest 99:297-304.

14. Hewison M, Rut AR, Kristjansson K, Walker RE, Dillon MJ, Hughes MR, O'Riordan JL 1993 Tissue resistance to 1,25dihydroxyvitamin $\mathrm{D}$ without a mutation of the vitamin $\mathrm{D}$ receptor gene. Clin Endocrinol 39:663-670.

15. Giraldo A, Pino W, Garcia-Ramirez LF, Pineda M, Iglesias A 1995 Vitamin D dependent rickets type II and normal vitamin D receptor cDNA sequence. A cluster in a rural area of Cauca, Colombia, with more than 200 affected children. Clin Genet 48:57-65.

16. Yoshizawa T, Handa Y, Uematsu Y, Takeda S, Sekine K, Yoshihara Y, Kawakami T, Arioka K, Sato H, Uchiyama Y, Masushige S, Fukamizu A, Matsumoto T, Kato S 1997 Mice lacking the vitamin $\mathrm{D}$ receptor exhibit impaired bone formation, uterine hypoplasia and growth retardation after weaning. Nat Genet 16:391-396.

17. Li YC, Pirro AE, Amling M, Delling G, Baron R, Bronson R, Demay MB 1997 Targeted ablation of the vitamin D receptor: An animal model of vitamin D-dependent rickets type II with alopecia. Proc Natl Acad Sci USA 94:9831-9835.

18. Li YC, Bergwitz C, Jüppner H, Demay MB 1997 Cloning and characterization of the vitamin D receptor from Xenopus laevis. Endocrinology 138:2347-2353.

19. Li Y, Pirro A, Amling M, Baron R, Bronson R, Demay M 1997 Vitamin D receptor knock-out mice develop hypocalcemia, hyperparathyroidism, rickets, osteomalacia and alopecia. J Bone Miner Res 12 (Suppl 1):S123 (abstract 81).

20. Balsan S, Garabedian M, Larchet M, Gorski AM, Cournot G, Tau C, Bourdeau A, Silve C, Ricour C 1986 Long-term nocturnal calcium infusions can cure rickets and promote normal 
mineralization in hereditary resistance to 1,25-dihydroxyvitamin D. J Clin Invest 77:1661-1667.

21. al-Aqeel A, Ozand P, Sobki S, Sewairi W, Marx S 1993 The combined use of intravenous and oral calcium for the treatment of vitamin D dependent rickets type II (VDDRII). Clin Endocrinol (Oxf) 39:229-237.

22. Takeda S, Yoshizawa T, Fukumoto S, Nagai Y, Murayama H, Matsumoto T, Kato S, Fujita T 1997 Bone metabolism and in vitro osteoclast formation in VDR knock-out mice. J Bone Miner Res 12 (Suppl 1):S110 (abstract 32).

23. Jimi E, Nakamura I, Amano H, Taguchi Y, Tsurukai T, Tamura M, Takahashi N, Suda T 1996 Osteoclast function is activated by osteoblastic cells through a mechanism involving cell-to-cell contact. Endocrinology 137:2187-2190.

24. Henry HL 1992 Vitamin D hydroxylases. J Cellular Biochem 49:4-9.

25. Brumbaugh PF, Hughes MR, Haussler MR 1975 Cytoplasmic and nuclear binding components for $1 \alpha, 25$-dihydroxyvitamin $\mathrm{D}_{3}$ in chick parathyroid glands. Proc Natl Acad Sci USA 72:4871-4875.

26. Hughes MR, Brumbaugh PF, Haussler MR, Wergedal JE, Baylink DJ 1975 Regulation of serum 1 $\alpha, 25$-dihydroxyvitamin $D_{3}$ by calcium and phosphate in the rat. Science 190:578-580.

27. Silver J, Russell J, Sherwood LM 1985 Regulation by vitamin D metabolites of messenger ribonucleic acid for preproparathyroid hormone in isolated bovine parathyroid cells. Proc Natl Acad Sci USA 82:4270-4273.

28. Sugimoto T, Brown AJ, Ritter C, Morrissey J, Slatopolsky E, Martin KJ 1989 Combined effects of dexamethasone and 1,25-dihydroxyvitamin $\mathrm{D}_{3}$ on parathyroid hormone secretion in cultured bovine parathyroid cells. Endocrinology 125: 638-641.

29. Mackey SL, Heymont JL, Kronenberg HM, Demay MB 1996 Vitamin D receptor binding to the negative human parathyroid hormone vitamin $\mathrm{D}$ response element does not require the retinoid X receptor. Mol Endocrinol 10:298305.

30. Reddy GS, Tserng KY 1989 Calcitroic acid, end product of renal metabolism of 1,25-dihydroxyvitamin $\mathrm{D}_{3}$ through $\mathrm{C}-24$ oxidation pathway. Biochemistry 28:1763-1769.

31. Tomon M, Tenenhouse HS, Jones G 1990 1,25-dihydroxyvitamin $\mathrm{D}_{3}$-inducible catabolism of vitamin $\mathrm{D}$ metabolites in mouse intestine. Am J Physiol 258:G557-G563.

32. Haussler MR, Pike JW, Dokoh S, Chandler JS, Chandler SK, Donaldson CA, Marion SL 1982 1,25-dihydroxyvitamin D receptor in cultured cell lines: Occurrence, subcellular distribution and relationship to bioresponses. In: Norman AW, Schaefer K, Herrath Dv, Grigoleit H-G (eds.) Vitamin D, Chemical, Biochemical and Clinical Endocrinology of Calcium Metabolism. Walter de Gruyter \& Co., Berlin-New York, pp. 109-113.

33. Ohyama Y, Ozono K, Uchida M, Shinki T, Kato S, Suda T, Yamamoto O, Noshiro M, Kato Y 1994 Identification of a vitamin D-responsive element in the $5^{\prime}$ flanking region of the rat 25-hydroxyvitamin $\mathrm{D}_{3}$ 24-hydroxylase gene. J Biol Chem 269:10545-10550.

34. St-Arnaud R, Arabian A, Travers R, Glorieux F 1997 Abnormal intramembranous ossification in mice deficient for the vitamin D-24-hydroxylase gene. In: Norman A, Bouillon R, Thomasset M (eds.) Vitamin D: Chemistry, Biology and Clinical Applications of the Steroid Hormone. University of California, Printing and Reprographics, Riverside, CA, U.S.A., pp. 635-639.

35. Henry HL, Norman AW 1978 Vitamin D: Two dihydroxylated metabolites are required for normal chicken egg hatchability. Science 201:835-837.

36. Nakamura T, Kurokawa T, Orimo H 1988 Increase of bone volume in vitamin D-repleted rats by massive administration of $24 \mathrm{R}, 25(\mathrm{OH})_{2} \mathrm{D}_{3}$. Calcif Tissue Int 43:235-243.

37. Schwartz Z, Dean DD, Walton JK, Brooks BP, Boyan BD 1995 Treatment of resting zone chondrocytes with 24,25dihydroxyvitamin $\mathrm{D}_{3}\left[24,25-(\mathrm{OH})_{2} \mathrm{D}_{3}\right]$ induces differentiation into a $1,25-(\mathrm{OH})_{2} \mathrm{D}_{3}-$ responsive phenotype characteristic of growth zone chondrocytes. Endocrinology 136:402-411.

38. Seino Y, Nakamura T, Tanaka H 1997 Role of $24 \mathrm{R}, 25(\mathrm{OH})_{2} \mathrm{D}_{3}$ in bone formation. In: Norman AW, Bouillon R, Thomasset M (eds.) Vitamin D: Chemistry, Biology and Clinical Applications of the Steroid Hormone. University of California, Printing and Reprographics, Riverside, CA, U.S.A., pp. 640-644.

39. DeMay MB, Kiernan MS, DeLuca HF, Kronenberg HM 1992 Sequences in the human parathyroid hormone gene that bind the 1,25-dihydroxyvitamin $\mathrm{D}_{3}$ receptor and mediate transcriptional repression in response to 1,25 -dihydroxyvitamin $\mathrm{D}_{3}$. Proc Natl Acad Sci USA 89:8097-8101.

40. Tenenhouse HS 1997 Cellular and molecular mechanisms of renal phosphate transport. J Bone Miner Res 12:159-164.

41. Taketani Y, Miyamoto K, Tanaka K, Katai K, Chikamori M, Tatsumi S, Segawa H, Yamamoto H, Morita K, Takeda E 1997 Gene structure and functional analysis of the human $\mathrm{Na}+/$ phosphate co-transporter. Biochem J 324: 927-934.

42. Drezner MK, Lyles KW, Haussler MR, Harrelson JM 1980 Evaluation of a role for 1,25-dihydroxyvitamin $\mathrm{D}_{3}$ in the pathogenesis and treatment of X-linked hypophosphatemic rickets and osteomalacia. J Clin Invest 66:1020-1032.

43. Harrel RM, Lyles KW, Harrelson JM, Drezner MK 1985 Healing of bone disease in X-linked hypohosphatemic rickets/ osteomalacia: Induction and maintenance with phosphorus and calcitriol. J Clin Invest 75:1858-1868.

44. Francis F, Hennig S, Korn B, Reinhardt R, de Jong P, Poustka A, Lehrach H, Rowe PSN, Goulding JN, Summerfield T, Mountford R, Read AP, Popowska E, Pronicka D, Davies KE, O'Riordan JLH, Econs MJ, Nesbitt T, Drezner MK, Oudet C, Pannetier S, Hanauer A, Strom TM, Meindl A, Lorenz B, Cagnoli M, Mohnike KL, Murken J, Meitinger T 1995 A gene (PEX) with homologies to endopeptidases is mutated in patients with $\mathrm{X}$-linked hypophosphatemic rickets. Nat Genet 11:130-136.

45. Parker MS, Klein I, Haussler MR, Mintz DH 1981 Tumorinduced osteomalacia: Evidence for a surgically correctable alteration in vitamin D metabolism. J Am Med Assoc 245: 492-493.

46. Nesbitt T, Coffman TM, Griffiths R, Drezner MK 1992 Crosstransplantation of kidneys in normal and hyp-mice: Evidence that the hyp-mouse phenotype is unrelated to an intrinsic renal defect. J Clin Invest 89:1453-1459.

47. Meyer RA, Meyer MH, Gray RW 1989 Parabiosis suggests a humoral factor is involved in X-linked hypophosphatemia in mice. J Bone Miner Res 4:493-500.

48. Econs MJ, Drezner MK 1994 Tumor-induced osteomalaciaUnveiling a new hormone. N Engl J Med 330:1679-1681.

49. Cai Q, Hodgson SF, Kao PC, Lennon VA, Klee GG, Zinmeister AR, Kumar R 1994 Inhibition of renal phosphate transport by a tumor product in a patient with oncogeneic osteomalacia. N Engl J Med 330:1645-1649.

50. Rowe PS, Goulding JN, Francis F, Oudet C, Econs MJ, Hanauer A, Lehrach H, Read AP, Mountford RC, Summerfield T, Weissenbach J, Fraser W, Drezner MK, Davies KE, O'Riordan JL 1996 The gene for X-linked hypohosphataemic rickets maps to a 200-300 kb region in Xp22.1, and is located on a single YAC containing a putative vitamin D response element (VDRE). Hum Genet 97:345-352.

51. Quesada JM, Martin-Malo A, Santiago J, Hervas F, Martinez ME, Castillo D, Barrio V, Aljama P 1990 Effect of calcitriol on insulin secretion in uraemia. Nephrol Dial Transplant 5:1013-1017.

52. Smith EL, Pincus SH, Donovan L, Holick MF 1988 A novel approach for the evaluation and treatment of psoriasis: Oral or topical use of 1,25-dihydroxyvitamin $\mathrm{D}_{3}$ can be a safe and effective therapy for psoriasis. J Am Acad Dermatol 19:516528.

53. Manolagas SC, Yu X-P, Girasole G, Bellido T 1994 Vitamin D and the hematolymphopoietic tissue: A 1994 update. Sem Nephrol 14:129-143. 
54. Casteels K, Bouillon R, Waer M, Mathieu C 1995 Immunomodulatory effects of 1,25-dihydroxyvitamin $\mathrm{D}_{3}$. Curr Opin Nephrol Hypertens 4:313-318.

55. Wientroub S, Winter CC, Wahl SM, Wahl LM 1989 Effect of vitamin $\mathrm{D}$ deficiency on macrophage and lymphocyte function in the rat. Calcif Tissue Int 44:125-130.

56. Lemire JM, Archer DC, Khulkarni A, Ince A, Uskokovic MR, Stephkowski $\mathrm{S} 1992$ The vitamin $\mathrm{D}_{3}$ analogue 1,25-dihydroxy$\Delta^{16}$-cholecalciferol prolongs the survival of murine cardiac allografts. Transplantation 54:762-763.

57. Lemire JM 1995 Immunomodulatory actions of 1,25-dihydroxyvitamin $\mathrm{D}_{3}$. J Steroid Biochem Mol Biol 53:599-602.

58. Reitsma PH, Rothberg PG, Astrin SM, Trial J, Bar-Shavit Z, Hall A, Teitelbaum SL, Kahn AJ 1983 Regulation of myc gene expression in HL-60 leukaemia cells by a vitamin D metabolite. Nature 306:492-494.

59. Mangelsdorf DJ, Koeffler HP, Donaldson CA, Pike JW, Haussler MR 1984 1,25-dihydroxyvitamin $\mathrm{D}_{3}$-induced differentiation in a human promyelocytic leukemia cell line (HL60): Receptor-mediated maturation to macrophage-like cells. J Cell Biol 98:391-398.

60. Branisteanu DD, Waer M, Sobis H, Marcelis S, Vandeputte M, Bouillon R 1995 Prevention of murine experimental allergic encephalomyelitis: Cooperative effects of cyclosporine and 1 alpha,25- $(\mathrm{OH})_{2} \mathrm{D}_{3}$. J Neuroimmunol 61:151-160.

61. Nataf S, Garcion E, Darcy F, Chabannes D, Muller JY, Brachet P 1996 1,25-dihydroxyvitamin $\mathrm{D}_{3}$ exerts regional effects in the central nervous system during experimental allergic encephalomyelitis. J Neuropathol Exp Neurol 55:904-914.

62. Naveilhan P, Neveu I, Wion D, Brachet P 1996 1,25-dihydroxyvitamin $\mathrm{D}_{3}$, an inducer of glial cell line-derived neurotrophic factor. Neuroreport 7:2171-2175.

63. Furman I, Baudet C, Brachet P 1996 Differential expression of M-CSF, LIF, and TNF-alpha genes in normal and malignant rat glial cells: Regulation by lipopolysaccharide and vitamin D. J Neurosci Res 46:360-366.

64. Neveu I, Naveilhan P, Baudet C, Brachet P, Metsis M 1994 1,25-dihydroxyvitamin $\mathrm{D}_{3}$ regulates NT-3, NT-4 but not BDNF mRNA in astrocytes. Neuroreport 6:124-126.

65. Neveu I, Naveilhan P, Jehan F, Baudet C, Funakosi H, Wion D, Brachet P, Metsis M 1994 1,25-dihydroxyvitamin $\mathrm{D}_{3}$ regulates the synthesis of nerve growth factor in primary cultures of glial cells. Brain Res 24:70-76.

66. Saporito MS, Brown ER, Hartpence KC, Wilcox HM, Vaught JL, Carswell S 1994 Chronic 1,25-dihydroxyvitamin $\mathrm{D}_{3}$-mediated induction of nerve growth factor mRNA and protein in L929 fibroblasts and in adult rat brain. Brain Res 633:189196

67. Sonnenberg J, Luine VN, Krey LC, Christakos S 1986 1,25Dihydroxyvitamin $\mathrm{D}_{3}$ treatment results in increased choline acetyltransferase activity in specific brain nuclei. Endocrinology 118:1433-1439.

68. Dowd DR, MacDonald PN, Komm BS, Haussler MR, Miesfeld RL 1992 Stable expression of the calbindin- $\mathrm{D}_{28 \mathrm{~K}}$ complementary DNA interferes with the apoptotic pathway in lymphocytes. Mol Endocrinol 6:1843-1848.

69. Airaksinen MS, Eilers J, Garaschuk O, Thoenen H, Konnerth A, Meyer M 1997 Ataxia and altered dendritic calcium signaling in mice carrying a targeted null mutation of the calbindin $\mathrm{D}_{28 \mathrm{k}}$ gene. Proc Natl Acad Sci USA 94:1488-1493.

70. Sutherland MK, Somerville MJ, Yoong LKK, Bergeron C, Haussler MR, McLachlan DRC 1992 Reduction of vitamin D hormone receptor mRNA levels in Alzheimer as compared to Huntington hippocampus: Correlation with calbindin- $\mathrm{D}_{28 \mathrm{k}}$ mRNA levels. Brain Res Mol Brain Res 13:239-250.

71. Maguire-Zeiss KA, Li ZW, Shimoda LM, Hamill RW 1995 Calbindin- $\mathrm{D}_{28 \mathrm{k}}$ mRNA in hippocampus, superior temporal gyrus and cerebellum: Comparison between control and Alzheimer disease subjects. Brain Res Mol Brain Res 30:362366.

72. Miyamoto K-I, Kesterson RA, Yamamoto H, Taketani Y, Nishiwaki E, Tatsumi S, Inoue Y, Morita K, Takeda E, Pike JW 1997 Structural organization of the human vitamin D receptor chromosomal gene and its promoter. Mol Endocrinol 11:1165-1179.

73. Faraco JH, Morrison NA, Baker A, Shine J, Frossard PM 1989 ApaI dimorphism at the human vitamin D receptor gene locus. Nucleic Acids Res 17:2150.

74. Laudet V, Begue A, Henry-Duthoit C, Joubel A, Martin P, Stehelin D, Saule S 1991 Genomic organization of the human thyroid hormone receptor $\alpha(c$-erbA-1) gene. Nucleic Acids Res 19:1105-1112.

75. Morrison NA, Qi JC, Tokita A, Kelly PJ, Crofts L, Nguyen TV, Sambrook PN, Eisman JA 1994 Prediction of bone density from vitamin D receptor alleles. Nature 367:284-287.

76. Morrison NA, Qi JC, Tokita A, Kelly PJ, Crofts L, Nguyen TV, Sambrook PN, Eisman JA 1997 Prediction of bone density from vitamin $\mathrm{D}$ receptor alleles [correction]. Nature 387:106.

77. Riggs BL, Nguyen TV, Melton LJI, Morrison NA, O'Fallon WM, Kelly PJ, Egan KS, Sambrook PN, Muhs JM, Eisman JA 1995 The contribution of vitamin D receptor gene alleles to the determination of bone mineral density in normal and osteoporotic women. J Bone Miner Res 10:991-996.

78. Fleet JC, Harris SS, Wood RJ, Dawson-Hughes B 1995 The BsmI vitamin D receptor restriction fragment length polymorphism (BB) predicts low bone density in premenopausal black and white women. J Bone Miner Res 10:985-990.

79. Hustmyer FG, Peacock M, Hui S, Johnston CC, Christian J 1994 Bone mineral density in relation to polymorphism at the vitamin D receptor gene locus. J Clin Invest 94:2130-2134.

80. Barger-Lux MJ, Heaney RP, Hayes J, DeLuca HF, Johnson ML, Gong G 1995 Vitamin D receptor gene polymorphism, bone mass, body size, and vitamin D receptor density. Calcif Tissue Int 57:161-162.

81. Lim SK, Park YS, Park JM, Song YD, Lee EJ, Kim KR, Lee HC, Huh KB 1995 Lack of association between vitamin D receptor genotypes and osteoporosis in Koreans. J Clin Endocrinol Metab 80:3677-3681.

82. Garnero P, Borel O, Sornay-Rendu E, Delmas PD 1995 Vitamin D receptor gene polymorphisms do not predict bone turnover and bone mass in healthy premenopausal women. J Bone Miner Res 10:1283-1288.

83. Houston LA, Grant SFA, Reid DM, Ralston SH 1996 Vitamin D receptor polymorphism, bone mineral density, and osteoporotic vertebral fracture: Studies in a UK population. Bone 18:249-252.

84. Cooper GS, Umbach DM 1996 Are vitamin D receptor polymorphisms associated with bone mineral density? A metaanalysis. J Bone Miner Res 11:1841-1849.

85. Ferrari S, Rizzoli R, Chevalley T, Slosman D, Eisman JA, Bonjour JP 1995 Vitamin-D-receptor-gene polymorphisms and change in lumbar-spine bone mineral density [see comments]. Lancet 345:423-424.

86. Salamone LM, Ferrell R, Black DM, Palermo L, Epstein RS, Petro N, Steadman N, Kuller LH, Cauley JA 1996 The association between vitamin $\mathrm{D}$ receptor gene polymorphisms and bone mineral density at the spine, hip and whole-body in premenopausal women. Osteoporos Int 6:63-68. (published erratum appears in Osteoporos Int 1996;6:187-188)

87. Viitanen A, Karkkainen M, Laitinen K, Lamberg-Allardt C, Kainulainen K, Rasanen L, Viikari J, Valimaki MJ, Kontula K 1996 Common polymorphism of the vitamin D receptor gene is associated with variation of peak bone mass in young Finns. Calcif Tissue Int 59:231-234.

88. McClure L, Eccleshall TR, Gross C, Villa ML, Lin N, Ramaswamy V, Kohlmeier L, Kelsey JL, Marcus R, Feldman D 1997 Vitamin D receptor polymorphisms, bone mineral density, and bone metabolism in postmenopausal MexicanAmerican women. J Bone Miner Res 12:234-240.

89. Feldman D 1997 Androgen and vitamin D receptor gene polymorphisms: The long and short of prostate cancer risk. J Natl Cancer Inst 89:109-111.

90. Carling T, Kindmark A, Hellman P, Holmberg L, Akerstrom G, Rastad J 1997 Vitamin D receptor alleles $b$, $a$, and T: Risk factors for sporadic primary hyperparathyroidism (HPT) but 
not HPT of uremia or MEN 1. Biochem Biophys Res Commun 231:329-332.

91. Taylor JA, Hirvonen A, Watson M, Pittman G, Mohler JL, Bell DA 1996 Association of prostate cancer with vitamin D receptor gene polymorphism. Cancer Res 56:4108-4110.

92. Ingles SA, Haile RW, Henderson BE, Kolonel LN, Nakaichi G, Shi CY, Yu MC, Ross RK, Coetzee GA 1997 Strength of linkage disequilibrium between two vitamin D receptor markers in five ethnic groups: Implications for association studies. Cancer Epidemiol Biomarkers Prev 6:93-98.

93. Ingles SA, Ross RK, Yu MC, Irvine RA, La Pera G, Haile RW, Coetzee GA 1997 Association of prostate cancer risk with genetic polymorphisms in vitamin $\mathrm{D}$ receptor and androgen receptor. J Natl Cancer Inst 89:166-170.

94. Ingles S, Haile R, Henderson B, Kolonel L, Coetzee G 1997 Association of vitamin D receptor genetic polymorphism with breast cancer risk in African-American and Hispanic women. In: Norman A, Bouillon R, Thomasset M (eds.) Vitamin D: Chemistry, Biology and Clinical Applications of the Steroid Hormone. University of California, Printing and Reprographics, Riverside, CA, U.S.A. pp. 813-814.

95. Karran P 1996 Microsatellite instability and DNA mismatch repair in human cancer. Semin Cancer Biol 7:15-24.

96. Arai H, Miyamoto K-I, Taketani Y, Yamamoto H, Iemori Y, Morita K, Tonai T, Nishisho T, Mori S, Takeda E 1997 A vitamin $\mathrm{D}$ receptor gene polymorphism in the translation initiation codon: Effect on protein activity and relation to bone mineral density in Japanese women. J Bone Miner Res 12:915-921.

97. Gross C, Eccleshall TR, Malloy PJ, Villa ML, Marcus R, Feldman D 1996 The presence of a polymorphism at the translation initiation site of the vitamin $\mathrm{D}$ receptor gene is associated with low bone mineral density in postmenopausal Mexican-American women. J Bone Miner Res 11:1850-1855.

98. Witte SM, Rogers J 1997 The short or 'F' form of the vitamin $\mathrm{D}$ receptor appears to be of recent evolutionary origin and unique to humans. J Bone Miner Res 12(Suppl 1):S371 (abstract F579).

99. MacDonald PN, Dowd DR, Nakajima S, Galligan MA, Reeder MC, Haussler CA, Ozato K, Haussler MR 1993 Retinoid $\mathrm{X}$ receptors stimulate and 9-cis retinoic acid inhibits, 1,25-dihydroxyvitamin $\mathrm{D}_{3}$-activated expression of the rat osteocalcin gene. Mol Cell Biol 13:5907-5917.

100. Cockerill FJ, Hawa NS, Yousaf N, Hewison M, O'Riordan JL, Farrow SM 1997 Mutations in the vitamin D receptor gene in three kindreds associated with hereditary vitamin $\mathrm{D}$ resistant rickets. J Clin Endocrinol Metab 82:3156-3160.

101. Hawa NS, Cockerill FJ, Vadher S, Hewison M, Rut AR, Pike JW, O'Riordan JL, Farrow SM 1996 Identification of a novel mutation in hereditary vitamin D resistant rickets causing exon skipping. Clin Endocrinol 45:85-92.

102. Rastinejad F, Perlmann T, Evans RM, Sigler PB 1995 Structural determinants of nuclear receptor assembly on DNA direct repeats. Nature 375:203-211.

103. Hsieh J-C, Shimizu Y, Minoshima S, Shimizu N, Galligan MA, Haussler CA, Haussler MR 1998 Identification of a nuclear localization signal between the zinc fingers of the human vitamin D receptor. J Cellular Biochem (in press).

104. Hsieh J-C, Jurutka PW, Galligan MA, Terpening CM, Haussler CA, Samuels DS, Shimizu Y, Shimizu N, Haussler MR 1991 Human vitamin D receptor is selectively phosphorylated by protein kinase $\mathrm{C}$ on serine 51 , a residue crucial to its trans-activation function. Proc Natl Acad Sci USA 88:93159319.

105. Hsieh J-C, Jurutka PW, Nakajima S, Galligan MA, Haussler CA, Shimizu Y, Shimizu N, Whitfield GK, Haussler MR 1993 Phosphorylation of the human vitamin $\mathrm{D}$ receptor by protein kinase C: Biochemical and functional evaluation of the serine 51 recognition site. J Biol Chem 268:15118-15126.

106. Walters R, Hunziker W, Norman AW 1980 Unoccupied 1,25dihydroxyvitamin $\mathrm{D}_{3}$ receptors. J Biol Chem 255:6799-6805.

107. Clemens TL, Garrett KP, Zhou X-Y, Pike JW, Haussler MR, Dempster DW 1988 Immunocytochemical localization of the 1,25-dihydroxyvitamin $\mathrm{D}_{3}$ receptor in target cells. Endocrinology 122: $1224-1230$

108. Berger U, Wilson P, McClelland RA, Colston K, Haussler MR, Pike JW, Coombes RC 1988 Immunocytochemical detection of 1,25-dihydroxyvitamin $\mathrm{D}$ receptors in normal human tissues. J Clin Endocrinol Metab 67:607-613.

109. Milde P, Merke J, Ritz E, Haussler MR, Rauterberg EW 1989 Immunohistochemical detection of 1,25-dihydroxyvitamin $\mathrm{D}_{3}$ receptors and estrogen receptors by monoclonal antibodies: Comparison of four immunoperoxidase methods. J Histochem Cytochem 37:1609-1617.

110. Zanello SB, Collins ED, Marinissen MJ, Norman AW, Boland RL 1997 Vitamin D receptor expression in chicken muscle tissue and cultured myoblasts. Horm Metab Res 29: 231-236.

111. Luo Z, Rouvinen J, Mäenpää PH 1994 A peptide C-terminal to the second $\mathrm{Zn}$ finger of human vitamin $\mathrm{D}$ receptor is able to specify nuclear localization. Eur J Biochem 223:381-387.

112. Simental JA, Sar M, Lane MV, French FS, Wilson EM 1991 Transcriptional activation and nuclear targeting signals of the human androgen receptor. J Biol Chem 266:510-518.

113. Guiochon-Mantel A, Loosfelt H, Lescop P, Sar S, Atger M, Perrot-Applanat M, Milgrom E 1989 Mechanisms of nuclear localization of the progesterone receptor: Evidence for interaction between monomers. Cell 57:1147-1154.

114. Picard D, Yamamoto KR 1987 Two signals mediate hormonedependent nuclear localization of the glucocorticoid receptor. EMBO J 6:3333-3340.

115. Barsony J, Renyi I, Mckoy W 1997 Subcellular distribution of normal and mutant vitamin D receptors in living cells. J Biol Chem 272:5774-5782.

116. Saijo T, Ito M, Takeda E, Mahbubul Hug AHM, Naito E, Yokota I, Sone T, Pike JW, Kuroda Y 1991 A unique mutation in the vitamin D receptor gene in three Japanese patients with vitamin D-dependent rickets type II: Utility of single stranded conformation polymorphism analysis for heterozygous carrier detection. Am J Hum Genet 49: 668-673.

117. Sackey FNA, Haché RJG, Reich T, Kwast-Welfeld J, Lefebvre YA 1996 Determinants of subcellular distribution of the glucocorticoid receptor. Mol Endocrinol 10:11911205.

118. Renaud J-P, Rochel N, Ruff M, Vivat V, Chambon P, Gronemeyer H, Moras D 1995 Crystal structure of the RAR- $\gamma$ ligand-binding domain bound to all-trans retinoic acid. Nature 378:681-689.

119. Wagner RL, Apriletti JW, McGrath ME, West BL, Baxter JD, Fletterick RJ 1995 A structural role for hormone in the thyroid hormone receptor. Nature 378:690-697.

120. Bourguet W, Ruff M, Chambon P, Gronemeyer H, Moras D 1995 Crystal structure of the ligand-binding domain of the human nuclear receptor RXR- $\alpha$. Nature 375:377-382.

121. Kristjansson K, Rut AR, Hewison M, O'Riordan JLH, Hughes MR 1993 Two mutations in the hormone binding domain of the vitamin $\mathrm{D}$ receptor cause tissue resistance to 1,25-dihydroxyvitamin $\mathrm{D}_{3}$. J Clin Invest 92:12-16.

122. Jones BB, Jurutka PW, Haussler CA, Haussler MR, Whitfield GK 1991 Vitamin D receptor phosphorylation in transfected ROS $17 / 2.8$ cells is localized to the N-terminal region of the hormone-binding domain. Mol Endocrinol 5:1137-1146.

123. Nakajima S, Hsieh J-C, Jurutka PW, Galligan MA, Haussler CA, Whitfield GK, Haussler MR 1996 Examination of the potential functional role of conserved cysteine residues in the hormone binding domain of the human 1,25-dihydroxyvitamin $\mathrm{D}_{3}$ receptor. J Biol Chem 271:5143-5149.

124. Nakajima S, Hsieh J-C, MacDonald PN, Galligan MA, Haussler CA, Whitfield GK, Haussler MR 1994 The C-terminal region of the vitamin $\mathrm{D}$ receptor is essential to form a complex with a receptor auxiliary factor required for high affinity binding to the vitamin D responsive element. Mol Endocrinol 8:159-172.

125. Wurtz J-M, Guillot B, Moras D 1997 3D model of the ligand binding domain of the vitamin $\mathrm{D}$ receptor based on the crystal 
structure of holo RAR $\gamma$. In: Norman AW, Bouillon R, Thomasset M (eds.) Vitamin D: Chemistry, Biology and Clinical Applications of the Steroid Hormone. University of California, Printing and Reprographics, Riverside, CA, U.S.A. pp. $165-172$.

126. Nishikawa J, Kitaura M, Imagawa M, Nishihara T 1995 Vitamin D receptor contains multiple dimerization interfaces that are functionally different. Nucleic Acids Res 23:606-611.

127. Hsieh J-C, Jurutka PW, Selznick SH, Reeder MC, Haussler CA, Whitfield GK, Haussler MR 1995 The T-box near the zinc fingers of the human vitamin $\mathrm{D}$ receptor is required for heterodimeric DNA binding and transactivation. Biochem Biophys Res Commun 215:1-7.

128. Rosen ED, Beninghof EG, Koenig RJ 1993 Dimerization interfaces of thyroid hormone, retinoic acid, vitamin $\mathrm{D}$, and retinoid X receptors. J Biol Chem 268:11534-11541.

129. Whitfield GK, Hsieh J-C, Nakajima S, MacDonald PN, Thompson PD, Jurutka PW, Haussler CA, Haussler MR 1995 A highly conserved region in the hormone binding domain of the human vitamin D receptor contains residues vital for heterodimerization with retinoid $\mathrm{X}$ receptor and for transcriptional activation. Mol Endocrinol 9:1166-1179.

130. Jin CH, Kerner SA, Hong MH, Pike JW 1996 Transcriptional activation and dimerization functions in the human vitamin D receptor. Mol Endocrinol 10:945-957.

131. Henttu PM, Kalkhoven E, Parker MG 1997 AF-2 activity and recruitment of steroid receptor coactivator 1 to the estrogen receptor depend on a lysine residue conserved in nuclear receptors. Mol Cell Biol 17:1832-1839.

132. Webster NJG, Green S, Jin JR, Chambon P 1988 The hormone binding domains of the estrogen and glucocorticoid receptors contain an inducible transcription activation function. Cell 54:199-207.

133. Danielian PS, White R, Lees JA, Parker MG 1992 Identification of a conserved region required for hormone dependent transcriptional activation by steroid hormone receptors. EMBO J 11:1025-1033.

134. Saatcioglu F, Deng T, Karin M 1993 A novel cis element mediating ligand-independent activation by c-ErbA: Implications for hormonal regulation. Cell 75:1095-1105.

135. Leng X, Blanco J, Tsai SY, Ozato K, O’Malley BW, Tsai M-J 1995 Mouse retinoid X receptor contains a separable ligandbinding and transactivation domain in its E region. Mol Cell Biol 15:255-263.

136. Jurutka PW, Hsieh J-C, Remus LS, Whitfield GK, Thompson PD, Haussler CA, Blanco JCG, Ozato K, Haussler MR 1997 Mutations in the 1,25-dihydroxyvitamin $\mathrm{D}_{3}$ receptor identifying C-terminal amino acids required for transcriptional activation that are functionally dissociated from hormone binding, heterodimeric DNA binding and interaction with basal transcription factor IIB, in vitro. J Biol Chem 272:1459214599.

137. Masuyama H, Brownfield CM, St-Arnaud R, MacDonald PN 1997 Evidence for ligand-dependent intramolecular folding of the AF-2 domain in vitamin $\mathrm{D}$ receptor-activated transcription and coactivator interaction. Mol Endocrinol 11: 15071517.

138. Haussler MR, Jurutka PW, Haussler CA, Hsieh J-C, Thompson PD, Remus LS, Selznick SH, Encinas C, Whitfield GK 1997 VDR-mediated transactivation: Interplay between $1,25(\mathrm{OH})_{2} \mathrm{D}_{3}$, RXR heterodimerization, transcription (co)factors and polymorphic receptor variants. In: Norman AW, Bouillon R, Thomasset M (eds.) Vitamin D: Chemistry, Biology and Clinical Applications of the Steroid Hormone. University of California, Printing and Reprographics, Riverside, CA, U.S.A. pp. 210-217.

139. Haussler MR, Jurutka PW, Hsieh J-C, Thompson PD, Selznick SH, Haussler CA, Whitfield GK 1994 Receptor mediated genomic actions of $1,25(\mathrm{OH})_{2} \mathrm{D}_{3}$ : Modulation by phosphorylation. In: Norman AW, Bouillon R, Thomasset M (eds.) Vitamin D: A Pluripotent Steroid Hormone: Structural Studies, Molecular Endocrinology and Clinical Applications. Walter de Gruyter, Berlin, Germany, pp. 209-216.
140. Brown TA, DeLuca HF 1990 Phosphorylation of the 1,25dihydroxyvitamin $\mathrm{D}_{3}$ receptor: A primary event in 1,25-dihydroxyvitamin $\mathrm{D}_{3}$ action. J Biol Chem 265:10025-10029.

141. Jurutka PW, Hsieh J-C, Haussler MR 1993 Phosphorylation of the human, 1,25-dihydroxyvitamin $\mathrm{D}_{3}$ receptor by cAMPdependent protein kinase, in vitro, and in transfected COS-7 cells. Biochem Biophys Res Commun 191:1089-1096.

142. Nakajima S, Yamagata M, Ozono K 1996 Effects of cyclic adenosine monophosphate and protein kinase-A on liganddependent transactivation via vitamin $\mathrm{D}$ receptor. J Bone Miner Res 11(Suppl 1):S162 (abstract P287).

143. Jurutka PW, Hsieh J-C, MacDonald PN, Terpening CM, Haussler CA, Haussler MR, Whitfield GK 1993 Phosphorylation of serine 208 in the human vitamin D receptor: The predominant amino acid phosphorylated by casein kinase II, in vitro, and identification as a significant phosphorylation site in intact cells. J Biol Chem 268:6791-6799.

144. Hilliard GM, Cook RG, Weigel NL, Pike JW 1994 1,25Dihydroxyvitamin $\mathrm{D}_{3}$ modulates phosphorylation of serine 205 in the human vitamin D receptor: Site-directed mutagenesis of this residue promotes alternative phosphorylation. Biochemistry 33:4300-4311.

145. Jurutka PW, Hsieh J-C, Nakajima S, Haussler CA, Whitfield GK, Haussler MR 1996 Human vitamin D receptor phosphorylation by casein kinase II at ser-208 potentiates transcriptional activation. Proc Natl Acad Sci USA 93:3519-3524.

146. Taneja R, Rochette-Egly C, Plassat JL, Penna L, Gaub MP, Chambon P 1997 Phosphorylation of activation functions AF-1 and AF-2 of RARalpha and RARgamma is indispensable for differentiation of F9 cells upon retinoic acid and cAMP treatment. EMBO J 16:6452-6465.

147. Baker AR, McDonnell DP, Hughes M, Crisp TM, Mangelsdorf DJ, Haussler MR, Pike JW, Shine J, O'Malley BW 1988 Cloning and expression of full-length cDNA encoding human vitamin D receptor. Proc Natl Acad Sci USA 85:3294-3298.

148. Burmester JK, Wiese RJ, Maeda N, DeLuca HF 1988 Structure and regulation of the rat 1,25-dihydroxyvitamin $\mathrm{D}_{3}$ receptor. Proc Natl Acad Sci USA 85:9499-9502.

149. Kamei Y, Kawada T, Fukuwatari T, Ono T, Kato S, Sugimoto E 1995 Cloning and sequencing of the gene encoding the mouse vitamin D receptor. Gene 152:281-282.

150. Haussler MR, Terpening CM, Jurutka PW, Meyer J, Schulman BA, Haussler CA, Whitfield GK, Komm BS 1988 Vitamin D hormone receptors: Structure, regulation and molecular function. In: Imura H, Shizume K, Yoshida S (eds.) Progress in Endocrinology. Elsevier Science Publishers B.V., Amsterdam, The Netherlands, pp. 763-770.

151. Lu Z, Hanson K, DeLuca HF 1997 Cloning and origin of the two forms of chicken vitamin D receptor. Arch Biochem Biophys 339:99-106.

152. Colnot S, Lambert M, Blin C, Thomasset M, Perret C 1995 Identification of DNA sequences that bind retinoid $\mathrm{X}$ receptor- $1,25(\mathrm{OH})_{2} \mathrm{D}_{3}$-receptor heterodimers with high affinity. Mol Cell Endocrinol 113:89-98.

153. Nishikawa J, Kitaura M, Matsumoto M, Imagawa M, Nishihara T 1994 Difference and similarity of DNA sequence recognized by VDR homodimer and VDR/RXR heterodimer. Nucleic Acids Res 22:2902-2907.

154. Jin CH, Pike JW 1996 Human vitamin D receptor-dependent transactivation in Saccharomyces cerevisiae requires retinoid X receptor. Mol Endocrinol 10:196-205.

155. MacDonald PN, Haussler CA, Terpening CM, Galligan MA, Reeder MC, Whitfield GK, Haussler MR 1991 Baculovirusmediated expression of the human vitamin D receptor: Functional characterization, vitamin D response element interactions, and evidence for a receptor auxiliary factor. J Biol Chem 266:18808-18813.

156. Staal A, van Wijnen AJ, Birkenhäger JC, Pols HA, Prahl J, DeLuca H, Gaub M-P, Lian JB, Stein GS, van Leeuwen JPTM, Stein JL 1996 Distinct conformations of vitamin D receptor/retinoid $\mathrm{X}$ receptor- $\alpha$ heterodimers are specified by dinucleotide differences in the vitamin D-responsive elements 
for the osteocalcin and osteopontin genes. Mol Endocrinol 10:1444-1456.

157. O'Connell TD, Simpson RU 1995 1,25-Dihydroxyvitamin $D_{3}$ regulation of myocardial growth and c-myc levels in the rat heart. Biochem Biophys Res Commun 213:59-65.

158. Pan Q, Martell RE, O'Connell TD, Simpson RU 1997 1,25Dihydroxyvitamin $\mathrm{D}_{3}$ regulation of c-myc expression and MIE binding proteins during HL-60 cell differentiation. In: Norman AW, Bouillon R, Thomasset M (eds.) Vitamin D: Chemistry, Biology and Clinical Application of the Steroid Hormone. University of California, Printing and Reprographics, Riverside, CA, U.S.A. pp. 306-307.

159. Alroy I, Towers TL, Freedman LP 1995 Transcriptional repression of the interleukin-2 gene by vitamin $\mathrm{D}_{3}$ : Direct inhibition of NFATp/AP-1 complex formation by a nuclear hormone receptor. Mol Cell Biol 15:5789-5799.

160. Breen EC, van Wijnen AJ, Lian JB, Stein GS, Stein JL 1994 In vivo occupancy of the vitamin $\mathrm{D}$ responsive element in the osteocalcin gene supports vitamin D-dependent transcriptional upregulation in intact cells. Proc Natl Acad Sci USA 91:12902-12906.

161. Koszewski NJ, Ashok S, Russell J 1996 Turning a negative into a positive: Mutation of the avian parathyroid hormone response element and vitamin D transcriptional activity. J Bone Miner Res 11(Suppl 1):S115 (abstract 83).

162. Lian JB, Shalhoub V, Aslam F, Frenkel B, Green J, Hamrah M, Stein GS, Stein JL 1997 Species-specific glucocorticoid and 1,25-dihydroxyvitamin $\mathrm{D}$ responsiveness in mouse MC3T3-E1 osteoblasts: Dexamethasone inhibits osteoblast differentiation and vitamin $\mathrm{D}$ down-regulates osteocalcin gene expression. Endocrinology 138:2117-2127.

163. Zhang R, Ducy P, Karsenty G 1997 1,25-dihydroxyvitamin $D_{3}$ inhibits osteocalcin expression in mouse through an indirect mechanism. J Biol Chem 272:110-116.

164. Kurokawa R, Söderström M, Hörlein A, Halachmi S, Brown M, Rosenfeld MG, Glass CK 1995 Polarity-specific activities of retinoic acid receptors determined by a co-repressor. Nature 377:451-454.

165. Rowland-Goldsmith MA, Henry HL 1997 Structure and regulatory elements of the vitamin D down-regulated gene for cAMP dependent protein kinase inhibitor (PKI). In: Norman AW, Bouillon R, Thomasset M (eds.) Vitamin D: Chemistry, Biology and Clinical Applications of the Steroid Hormone. University of California, Printing and Reprographics, Riverside, CA, U.S.A. pp. 300-301.

166. Forman BM, Umesono K, Chen J, Evans RM 1995 Unique response pathways are established by allosteric interactions among nuclear hormone receptors. Cell 81:541-550.

167. Chen J-Y, Clifford J, Zsui C, Starrett J, Tortolani D, Ostrowski J, Reczek PR, Chambon P, Gronemeyer H 1996 Two distinct actions of retinoid-receptor ligands. Nature 382:819 822 .

168. Minucci S, Leid M, Toyama R, Saint-Jeannet J-P, Peterson VJ, Horn V, Ishmael JE, Bhattacharyya N, Dey A, Dawid IB, Ozato K 1997 Retinoid X receptor (RXR) within the RXRretinoic acid receptor heterodimer binds its ligand and enhances retinoid-dependant gene expression. Mol Cell Biol 17:644-655.

169. Zugmaier G, Jäger R, Grage B, Gottardis MM, Havemann K, Knabbe C 1996 Growth-inhibitory effects of vitamin D analogues and retinoids on human pancreatic cancer cells. Br J Cancer 73:1341-1346.

170. Kane KF, Langman MJS, Williams GR 1996 Antiproliferative responses of two human colon cancer cell lines to vitamin $D_{3}$ are differentially modified by 9-cis-retinoic acid. Cancer Res 56:623-632.

171. Kang S, Xiao-Yan L, Duell EA, Voorhees J 1997 The retinoid $\mathrm{X}$ receptor agonist 9-cis-retinoic acid and the 24-hydroxylase inhibitor ketoconazole increase activity of 1,25-dihydroxyvitamin $\mathrm{D}_{3}$ in human skin in vivo. J Invest Dermatol 108:513-518.

172. Li XY, Xiao JH, Feng X, Qin L, Voorhees JJ 1997 Retinoid $\mathrm{X}$ receptor-specific ligands synergistically upregulate 1,25 dihydroxyvitamin $\mathrm{D}_{3}$-dependent transcription in epidermal keratinocytes in vitro and in vivo. J Invest Dermatol 108:506512.

173. Blutt SE, Allegretto EA, Pike JW, Weigel NL 1997 1,25dihydroxyvitamin $\mathrm{D}_{3}$ and 9-cis-retinoic acid act synergistically to inhibit the growth of $\mathrm{LNCaP}$ prostate cells and cause accumulation of cells in G1. Endocrinology 138:1491-1497.

174. Carlberg C, Bendik I, Wyss A, Meier E, Sturzenbecker LJ, Grippo JF, Hunziker W 1993 Two nuclear signalling pathways for vitamin D. Nature 361:657-660.

175. Lemon BD, Freedman LP 1996 Selective effects of ligands on vitamin $\mathrm{D}_{3}$ receptor- and retinoid $\mathrm{X}$ receptor-mediated gene activation in vivo. Mol Cell Biol 16:1006-1016.

176. Zou A, Elgort MG, Allegretto EA 1997 Retinoid X receptor (RXR) ligands activate the human 25-hydroxyvitamin $\mathrm{D}_{3}$ 24-hydroxylase promoter via RXR heterodimer binding to two vitamin D-responsive elements and elicit additive effects with 1,25-dihydroxyvitamin $\mathrm{D}_{3}$. J Biol Chem 272: 19027-19034.

177. Guo B, Aslam F, Van Wijnen A, Roberts SGE, Frenkel B, Green MR, DeLuca H, Lian JB, Stein GS, Stein J 1997 YY1 regulates vitamin $\mathrm{D}$ receptor/retinoid $\mathrm{X}$ receptor mediated transactivation of the vitamin $\mathrm{D}$ responsive osteocalcin gene. Proc Natl Acad Sci USA 94:121-126.

178. Liu M, Freedman LP 1994 Transcriptional synergism between the vitamin $\mathrm{D}_{3}$ receptor and other nonreceptor transcription factors. Mol Endocrinol 8:1593-1604.

179. Candeliere GA, Jurutka PW, Haussler MR, St-Arnaud R 1996 A composite element binding the vitamin D receptor, retinoid X receptor $\alpha$, and a member of the CTF/NF-1 family of transcription factors mediates the vitamin $\mathrm{D}$ responsiveness of the c-fos promoter. Mol Cell Biol 16:584-592.

180. Krause KH, Michalak M 1997 Calreticulin. Cell 88:439443.

181. Chen JD, Evans RM 1995 A transcriptional co-repressor that interacts with nuclear hormone receptors. Nature 377:454457.

182. Perlmann T, Evans RM 1997 Nuclear receptors in Sicily: All in the famiglia. Cell 90:391-397.

183. Horwitz KB, Jackson TA, Bain DL, Richer JK, Takimoto GS, Tung L 1996 Nuclear receptor coactivators and corepressors. Mol Endocrinol 10:1167-1177.

184. Edmondson DG, Roth SY 1996 Chromatin and transcription. FASEB J 10:1173-1182.

185. Makino Y, Yamano K, Kanemaki M, Morikawa K, Kishimoto T, Shimbara N, Tanaka K, Tamura T 1997 SUG1, a component of the $26 \mathrm{~S}$ proteasome, is an ATPase stimulated by specific RNAs. J Biol Chem 272:23201-23205.

186. Masuyama H, Dowd DR, Brown AJ, MacDonald PN 1997 Proteasome-mediated degradation of the vitamin $\mathrm{D}$ receptor (VDR) and the potential involvement of a $1,25-(\mathrm{OH})_{2} \mathrm{D}_{3}-$ dependent interaction between the VDR AF-2 domain and SUG1. J Bone Miner Res 12(Suppl. 1):S122 (abstract 79).

187. vom Baur E, Zechel C, Heery D, Heine MJS, Garnier JM, Vivat V, Chambon P, Losson R 1996 Differential liganddependent interactions between the AF-2 activating domain of nuclear receptors and the putative transcriptional intermediary factors mSUG1 and TIF1. EMBO J 15:110-124.

188. Lemon BD, Fondell JD, Freedman LP 1997 Retinoid X receptor:vitamin $\mathrm{D}_{3}$ receptor heterodimers promote stable preinitiation complex formation and direct 1,25-dihydroxyvitamin $\mathrm{D}_{3}$-dependent cell-free transcription. Mol Cell Biol 17:1923-1937.

189. Brown AJ, Dusso A, Slatopolsky E 1994 Selective vitamin D analogs and their therapeutic applications. Sem Nephrol 14:156-174.

190. Bouillon R, Okamura WH, Norman AW 1995 Structurefunction relationships in the vitamin $\mathrm{D}$ endocrine system. Endocr Rev 16:200-257.

191. Peleg S, Sastry M, Collins ED, Bishop JE, Norman AW 1995 Distinct conformational changes induced by 20 -epi analogues of $1 \alpha, 25$-dihydroxyvitamin $\mathrm{D}_{3}$ are associated with enhanced activation of the vitamin D receptor. J Biol Chem 270:1055110558. 
192. Abe J, Takita Y, Nakano T, Miyaura C, Suda T, Nishii Y 1989 A synthetic analogue of vitamin $\mathrm{D}_{3}, 22$-oxa- $1 \alpha, 25$-dihydroxyvitamin $\mathrm{D}_{3}$, is a potent modulator of in vivo immunoregulating activity without inducing hypercalcemia in mice. Endocrinology 124:2645-2647.

193. Brown AJ, Ritter CS, Finch JL, Morrissey J, Martin KJ, Murayama E, Nishii Y, Slatopolsky E 1989 The noncalcemic analogue of vitamin D, 22-oxacalcitriol, suppresses parathyroid hormone synthesis and secretion. J Clin Invest 84:728732.

194. Cheskis B, Lemon BD, Uskokovic M, Lomedico PT, Freedman LP 1995 Vitamin $\mathrm{D}_{3}$-retinoid X receptor dimerization, DNA binding, and transactivation are differentially affected by analogs of 1,25-dihydroxyvitamin $\mathrm{D}_{3}$. Mol Endocrinol 9:1814-1824.

195. Reichrath J, Muller SM, Kerber A, Baum HP, Bahmer FA 1997 Biologic effects of topical calcipotriol (MC 903) treatment in psoriatic skin. J Am Acad Dermatol 36:19-28.

196. Mehta RG, Moriarty RM, Mehta RR, Penmasta R, Lazzaro G, Constantinou A, Guo L 1997 Prevention of preneoplastic mammary lesion development by a novel vitamin $\mathrm{D}$ analogue, $1 \alpha$-hydroxyvitamin $\mathrm{D}_{5}$. J Natl Cancer Inst 89:212-218.

197. van den Bemd GC, Pols HA, Birkenhäger JC, van Leeuwen JP 1996 Conformational change and enhanced stabilization of the vitamin $\mathrm{D}$ receptor by the 1,25 -dihydroxyvitamin $\mathrm{D}_{3}$ analog KH1060. Proc Natl Acad Sci USA 93:10685-10690.

198. Liu YY, Collins ED, Norman AW, Peleg S 1997 Differential interaction of 1alpha,25-dihydroxyvitamin $\mathrm{D}_{3}$ analogues and their 20-epi homologues with the vitamin D receptor. J Biol Chem 272:3336-3345.

199. Zhao XY, Eccleshall TR, Krishnan AV, Gross C, Feldman D 1997 Analysis of vitamin D analog-induced heterodimerization of vitamin D receptor with retinoid X receptor using the yeast two-hybrid system. Mol Endocrinol 11:366-378.

200. Ishizuka S, Miura D, Manabe K, Gao Q, Sakuma Y, Uno H, Ozono K 1997 Novel 1 $\alpha, 25$-dihydroxyvitamin $D_{3}$-26,23-lactone analogues function as antagonists of vitamin D receptormediated genomic actions of $1 \alpha, 25$-dihydroxyvitamin $\mathrm{D}_{3}$. J Bone Miner Res 12(Suppl 1):S452 (abstract S399).

201. Ozono K, Ito M, Miura D, Ishizuka S, Yanagihara I, Nakajima S 1997 Novel 1 $\alpha$,25-dihydroxyvitamin $\mathrm{D}_{3}$ analogue, TEI9647 , acts as an antagonist of the vitamin D receptor. J Bone Miner Res 12(Suppl 1):S122 (abstract 78).

202. Reichel H, Koeffler HP, Tobler A, Norman AW 19871 alpha,25-Dihydroxyvitamin $\mathrm{D}_{3}$ inhibits gamma-interferon synthesis by normal human peripheral blood lymphocytes. Proc Natl Acad Sci USA 84:3385-3389.

203. Barna M, Bos JD, Kapsenberg ML, Snijdewint FG 1997 Effect of calcitriol on the production of T-cell-derived cytokines in psoriasis. Br J Dermatol 136:536-541.

204. Johnson JA, Grande JP, Windebank AJ, Kumar R 1996 1,25-dihydroxyvitamin $\mathrm{D}_{3}$ receptors in developing dorsal root ganglia of fetal rats. Brain Res Dev Brain Res 92:120-124.

205. Musiol IM, Feldman D 1997 1,25-dihydroxyvitamin $D_{3}$ induction of nerve growth factor in L929 mouse fibroblasts: Effect of vitamin $D_{3}$ analogs. Endocrinology 116:149-156.

206. Rizk-Rabin M, Zineb R, Zhor B, Michele G, Jana P 1994 Synthesis of and response to 1,25 dihydroxycholecalciferol by subpopulations of murine epidermal keratinocytes: Existence of a paracrine system for 1,25 dihydroxycholecalciferol. J Cell Physiol 159:131-141.

207. Reichrath J, Schilli M, Kerber A, Bahmer FA, Czarnetzki BM, Paus R 1994 Hair follicle expression of 1,25-dihydroxyvitamin $\mathrm{D}_{3}$ receptors during the murine hair cycle. Br J Dermatol 131:477-482.

208. Johnson JA, Grande JP, Roche PC, Kumar R 1996 Immunohistochemical detection and distribution of the 1,25-dihydroxyvitamin $\mathrm{D}_{3}$ receptor in rat reproductive tissues. Histochem Cell Biol 105:7-15.

209. Peehl DM, Skowronski RJ, Leung GK, Wong ST, Stamey TA, Feldman D 1994 Antiproliferative effects of 1,25-dihydroxyvitamin $\mathrm{D}_{3}$ on primary cultures of human prostatic cells. Cancer Res 54:805-810.
210. Giuliano AR, Franceschi RT, Wood RJ 1991 Characterization of the vitamin $\mathrm{D}$ receptor from the Caco-2 human colon carcinoma cell line: Effect of cellular differentiation. Arch Biochem Biophys 285:261-269.

211. Bikle DD, Pillai S 1993 Vitamin D, calcium and epidermal differentiation. Endocr Rev 14:3-19.

212. Limat A, Hunziker T, Braathen LR 1993 Effects of 1 alpha,25-dihydroxy-vitamin $\mathrm{D}_{3}$ and calcipotriol on organotypic cultures of outer root sheath cells: A potential model to evaluate antipsoriatic drugs. Arch Dermatol Res 285: 402-409.

213. Narvaez CJ, Welsh J 1997 Differential effects of 1,25-dihydroxyvitamin $\mathrm{D}_{3}$ and tetradecanoylphorbol acetate on cell cycle and apoptosis of MCF-7 cells and a vitamin $\mathrm{D}_{3}$-resistant variant. Endocrinology 138:4690-4698.

214. Thomas MG, Tebbutt S, Williamson RCN 1992 Vitamin D and its metabolites inhibit cell proliferation in human rectal mucosa and a colon cancer cell line. Gut 33:1660-1663.

215. Nguyen TM, Guillozo H, Marin L, Tordet C, Koite S, Garabedian M 1996 Evidence for a vitamin D paracrine system regulating maturation of developing rat lung epithelium. Am J Physiol 271:L392-L399.

216. Stumpf WE, Sar M, Reid FA, Tanaka Y, DeLuca HF 1979 Target cells for 1,25-dihydroxyvitamin $\mathrm{D}_{3}$ in intestinal tract, stomach, kidney, skin, pituitary, and parathyroid. Science 206: $1188-1190$

217. Johnson JA, Grande JP, Roche PC, Kumar R 1994 Immunohistochemical localization of the $1,25(\mathrm{OH})_{2} \mathrm{D}_{3}$ receptor and calbindin $\mathrm{D}_{28 \mathrm{k}}$ in human and rat pancreas. Am J Physiol 267:E356-E360.

218. Atley LM, Lefroy N, Wark JD 1995 1,25-dihydroxyvitamin $\mathrm{D}_{3}$-induced upregulation of the thyrotropin-releasing hormone receptor in clonal rat pituitary $\mathrm{GH}_{3}$ cells. J Endocrinol 147:397-404.

219. Berg JP, Liane KM, Bjorhovde SB, Bjoro T, Torjesen PA Haug E 1994 Vitamin D receptor binding and biological effects of cholecalciferol analogues in rat thyroid cells. J Steroid Biochem Mol Biol 50:145-150.

220. Dokoh S, Donaldson CA, Marion SL, Pike JW, Haussler MR 1983 The ovary: A target organ for 1,25-dihydroxyvitamin $\mathrm{D}_{3}$. Endocrinology 112:200-206.

221. Bidmon HJ, Gutkowska J, Murakami R, Stumpf WE 1991 Vitamin D receptors in heart: Effects on atrial natriuretic factor. Experientia 47:958-962.

222. Li Q, Gardner DG 1994 Negative regulation of the human atrial natriuretic peptide gene by 1,25-dihydroxyvitamin $D_{3}$. J Biol Chem 269:4934-4939.

223. Wu J, Garami M, Cheng T, Gardner DG 1996 1,25(OH) Vitamin $\mathrm{D}_{3}$ and retinoic acid antagonize endothelin-stimulated hypertrophy of neonatal rat cardiac myocytes. J Clin Invest 97:1577-1588.

224. Kawada T, Kamei Y, Sugimoto E 1996 The possibility of active form of vitamins $\mathrm{A}$ and $\mathrm{D}$ as suppressors on adipocyte development via ligand-dependent transcriptional regulators. Int J Obes Relat Metab Disord 20(Suppl 3):S52-S57.

225. Vu D, Ong JM, Clemens TL, Kern PA 1996 1,25-dihydroxyvitamin D induces lipoprotein lipase expression in 3T3-L1 cells in association with adipocyte differentiation. Endocrinology 137:1540-1544.

226. Hedlund TE, Moffatt KA, Miller GJ 1996 Stable expression of the nuclear vitamin D receptor in the human prostatic carcinoma cell line JCA-1: Evidence that the antiproliferative effects of $1 \alpha, 25$-dihydroxyvitamin $\mathrm{D}_{3}$ are mediated exclusively through the genomic signaling pathway. Endocrinology 137: 1554-1561.

227. Yabushita H, Hirata M, Noguchi M, Nakanishi M 1996 Vitamin D receptor in endometrial carcinoma and the differentiation-inducing effect of 1,25-dihydroxyvitamin $\mathrm{D}_{3}$ on endometrial carcinoma cell lines. J Obstet Gynaecol Res 22:529539.

228. Liu M, Lee MH, Bommakanti M, Freedman LP 1996 Transcriptional activation of the Cdk inhibitor $\mathrm{p} 21$ by vitamin $\mathrm{D}_{3}$ 
leads to the induced differentiation of the myelomonocytic cell line U937. Genes Dev 10:142-153.

229. Kawa S, Nikaido T, Aoki Y, Zhai Y, Kumagai T, Furihata K, Fujii S, Kiyosawa K 1997 Vitamin D analogues up-regulate p21 and p27 during growth inhibition of pancreatic cancer cell lines. Br J Cancer 76:884-889.

230. Rots NY, Freedman LP 1997 Induction of myeloid cell differentiation by overexpression of different direct target genes of the $1 \alpha, 25(\mathrm{OH})_{2} \mathrm{D}_{3}$ receptor. In: Norman $\mathrm{AW}$, Bouillon R, Thomasset M (eds.) Vitamin D: Chemistry, Biology and Clinical Applications of the Steroid Hormone. University of California, Printing and Reprographics, Riverside, CA, U.S.A., pp. 423-424.

231. Elstner E, Linker-Israeli M, Umiel T, Le J, Grillier I, Said J, Shintaku IP, Krajewski S, Reed JC, Binderup L, Koeffler HP 1996 Combination of a potent 20-epi-vitamin $\mathrm{D}_{3}$ analogue (KH 1060) with 9-cis-retinoic acid irreversibly inhibits clonal growth, decreases bcl-2 expression, and induces apoptosis in HL-60 leukemic cells. Cancer Res 56:3570-3576.

232. Simboli-Campbell M, Narvaez CJ, van Weelden K, Tenniswood M, Welsh J 1997 Comparative effects of $1,25(\mathrm{OH})_{2} \mathrm{D}_{3}$ and EB1089 on cell cycle kinetics and apoptosis in MCF-7 breast cancer cells. Breast Cancer Res Treat 42:31-41.

233. DeMay MB, Gerardi JM, DeLuca HF, Kronenberg HM 1990 DNA sequences in the rat osteocalcin gene that bind the 1,25-dihydroxyvitamin $\mathrm{D}_{3}$ receptor and confer responsiveness to 1,25-dihydroxyvitamin $\mathrm{D}_{3}$. Proc Natl Acad Sci USA 87: 369-373.

234. Markose ER, Stein JL, Stein GS, Lian JB 1990 Vitamin D-mediated modifications in protein-DNA interactions at two promoter elements of the osteocalcin gene. Proc Natl Acad Sci USA 87:1701-1705.

235. Terpening CM, Haussler CA, Jurutka PW, Galligan MA, Komm BS, Haussler MR 1991 The vitamin D-responsive element in the rat bone gla protein is an imperfect direct repeat that cooperates with other cis-elements in 1,25-dihydroxyvitamin $\mathrm{D}_{3}$-mediated transcriptional activation. Mol Endocrinol 5:373-385.

236. Kerner SA, Scott RA, Pike JW 1989 Sequence elements in the human osteocalcin gene confer basal activation and inducible response to hormonal vitamin $\mathrm{D}_{3}$. Proc Natl Acad Sci USA 86:4455-4459.

237. Morrison NA, Shine J, Fragonas J-C, Verkest V, McMenemy L, Eisman JA 1989 1,25-dihydroxyvitamin D-responsive element and glucocorticoid repression in the osteocalcin gene. Science 246:1158-1161.

238. Ozono K, Liao J, Kerner SA, Scott RA, Pike JW 1990 The vitamin D-responsive element in the human osteocalcin gene: Association with a nuclear proto-oncogene enhancer. J Biol Chem 265:21881-21888.

239. Noda M, Vogel RL, Craig AM, Prahl J, DeLuca HF, Denhardt DT 1990 Identification of a DNA sequence responsible for binding of the 1,25-dihydroxyvitamin $\mathrm{D}_{3}$ receptor and 1,25-dihydroxyvitamin $\mathrm{D}_{3}$ enhancement of mouse secreted phosphoprotein 1 (Spp-1 or osteopontin) gene expression. Proc Natl Acad Sci USA 87:9995-9999.

240. Cao X, Ross FP, Zhang L, MacDonald PN, Chappel J, Teitelbaum SL 1993 Cloning of the promoter for the avian integrin $\beta_{3}$ subunit gene and its regulation by 1,25-dihydroxyvitamin $\mathrm{D}_{3}$. J Biol Chem 268:27371-27380.

241. Jurutka PW, Hsieh J-C, Haussler MR 1994 Characterization of a new functional 1,25-dihydroxyvitamin $\mathrm{D}_{3}$ responsive element in the promoter region of the rat 25-hydroxyvitamin $\mathrm{D}_{3}$ 24-hydroxylase gene. J Bone Miner Res 9(Suppl 1):S160 (abstract 157).

242. Zierold C, Darwish HM, DeLuca HF 1994 Identification of a vitamin D-responsive element in the rat calcidiol (25-hydroxyvitamin $\mathrm{D}_{3}$ ) 24-hydroxylase gene. Proc Natl Acad Sci USA 91:900-902.

243. Gill RK, Christakos S 1993 Identification of sequence elements in mouse calbindin- $\mathrm{D}_{28 \mathrm{~K}}$ gene that confer 1,25 -dihydroxyvitamin $\mathrm{D}_{3}$ - and butyrate-inducible responses. Proc Natl Acad Sci USA 90:2984-2988.
244. Liu SM, Koszewski N, Lupez M, Malluche HH, Olivera A, Russell J 1996 Characterization of a response element in the 5 '-flanking region of the avian (chicken) PTH gene that mediates negative regulation of gene transcription by 1,25-dihydroxyvitamin $\mathrm{D}_{3}$ and binds the vitamin $\mathrm{D}_{3}$ receptor. Mol Endocrinol 10:206-215.

245. Kim RH, Li JJ, Ogata Y, Yamauchi M, Freedman LP, Sodek J 1996 Identification of a vitamin $D_{3}$-response element that overlaps a unique inverted TATA box in the rat bone sialoprotein gene. Biochem J 318:219-226.

246. Falzon M 1996 DNA sequences in the rat parathyroid hormone-related peptide gene responsible for 1,25-dihydroxyvitamin $\mathrm{D}_{3}$-mediated transcriptional repression. Mol Endocrinol 10:672-681.

247. Kremer R, Sebag M, Champigny C, Meerovitch K, Hendy GN, White J, Goltzman D 1996 Identification and characterization of 1,25-dihydroxyvitamin $\mathrm{D}_{3}$-responsive repressor sequences in the rat parathyroid hormone-related peptide gene. J Biol Chem 271:16310-16316.

248. Tsonis PA, Sargent MT, Del Rio-Tsonis K, Jung JC 1996 9-cis retinoic acid antagonizes the stimulatory effect of 1,25 dihydroxyvitamin $\mathrm{D}_{3}$ on chrondrogenesis of chick limb bud mesenchymal cells: Interactions of their receptors. Int J Dev Biol 40:1053-1059.

249. Cheskis B, Freedman LP 1994 Ligand modulates the conversion of DNA-bound vitamin $\mathrm{D}_{3}$ receptor (VDR) homodimers into VDR-retinoid X receptor heterodimers. Mol Cell Biol 14:3329-3338.

250. Thompson PD, Jurutka PW, Haussler CA, Whitfield GK, Haussler MR 1998 Heterodimeric DNA binding by the vitamin $\mathrm{D}$ receptor and retinoid $\mathrm{X}$ receptors is enhanced by 1,25-dihydroxyvitamin $\mathrm{D}_{3}$ and inhibited by 9-cis retinoic acid: Evidence for allosteric receptor interactions. J Biol Chem (in press).

251. Nakajima H, Kizaki M, Ueno H, Muto A, Takayama N, Matsushita H, Sonoda A, Ikeda Y 1996 All-trans and 9-cis retinoic acid enhance differentiation of U937 cells. Leuk Res 20:665-676.

252. Defacque H, Dornand J, Commes T, Cabane S, Sevilla C, Marti J 1994 Different combinations of retinoids and vitamin $\mathrm{D}_{3}$ analogs efficiently promote growth inhibition and differentiation of myelomonocytic leukemia cell lines. J Pharmacol Exp Ther 271:193-199.

253. Bunce CM, Wallington LA, Harrison P, Williams GR, Brown G 1995 Treatment of HL60 cells with various combinations of retinoids and 1 alpha,25-dihydroxyvitamin $\mathrm{D}_{3}$ results in differentiation towards neutrophils or monocytes or a failure to differentiate and apoptosis. Leukemia 9:410-418.

254. James SY, Mackay AG, Colston KW 1995 Vitamin D derivatives in combination with 9-cis retinoic acid promote active cell death in breast cancer cells. J Mol Endocrinol 14:391-394

255. Kato S, Sasaki H, Suzawa M, Masushige S, Tora L, Chambon P, Gronemeyer H 1995 Widely spaced, directly repeated PuGGTCA elements act as promiscuous enhancers for different classes of nuclear receptors. Mol Cell Biol 15:58585867.

256. Kephart DD, Walfish PG, DeLuca H, Butt TR 1996 Retinoid $\mathrm{X}$ receptor isotype identity directs human vitamin $\mathrm{D}$ receptor heterodimer transactivation from the 24-hydroxylase vitamin D response elements in yeast. Mol Endocrinol 10:408-419.

257. Schräder M, Nayeri S, Kahlen J-P, Müller KM, Carlberg C 1995 Natural vitamin $\mathrm{D}_{3}$ response elements formed by inverted palindromes: Polarity-directed ligand sensitivity of vitamin $\mathrm{D}_{3}$ receptor-retinoid $\mathrm{X}$ receptor heterodimer-mediated transactivation. Mol Cell Biol 15:1154-1161.

258. Sneddon WB, Bogado CE, Kiernan MS, Demay MB 1997 DNA sequences downstream from the vitamin D response element of the rat osteocalcin gene are required for liganddependent transactivation. Mol Endocrinol 11:210-217.

259. Ohyama Y, Ozono K, Uchida M, Yoshimura M, Shinki T, Suda T, Yamamoto O 1996 Functional assessment of two 
vitamin D-responsive elements in the rat 25-hydroxyvitamin $\mathrm{D}_{3}$ 24-hydroxylase gene. J Biol Chem 271:30381-30385.

260. Wheeler DG, Horsford J, Michalak M, White JH, Hendy GN 1995 Calreticulin inhibits vitamin $\mathrm{D}_{3}$ signal transduction. Nucleic Acids Res 23:3268-3274.

261. Kim YS, MacDonald PN, Dedhar S, Hruska KA 1996 Association of $1 \alpha, 25$-dihydroxyvitamin $\mathrm{D}_{3}$-occupied vitamin $\mathrm{D}$ receptors with cellular membrane acceptance sites. Endocrinology 137:3649-3658.

262. Imai T, Matsuda K, Shimojima T, Hashimoto T, Masuhiro Y, Kitamoto Sugita A, Suzuiki K, Matsumoto H, Masushige S, Nogi Y, Muramatsu M, Handa H, Kato S 1997 ERC-55, a binding protein for the papilloma virus E6 oncoprotein, specifically interacts with vitamin D receptor among nuclear receptors. Biochem Biophys Res Commun 233:765-769.

263. Schulman IG, Juguilon H, Evans RM 1996 Activation and repression by nuclear hormone receptors: Hormone modulates an equilibrium between active and repressive states. Mol Cell Biol 16:3807-3813.

264. MacDonald PN, Sherman DR, Dowd DR, Jefcoat SC Jr, DeLisle RK 1995 The vitamin D receptor interacts with general transcription factor IIB. J Biol Chem 270:47484752.

265. Hong H, Kohli K, Garabedian MJ, Stallcup MR 1997 GRIP1, a transcriptional coactivator for the AF-2 transactivation domain of steroid, thyroid, retinoid, and vitamin D receptors. Mol Cell Biol 17:2735-2744.

266. Chen H, Lin RJ, Schiltz RL, Chakravarti D, Nash A, Nagy L, Privalsky ML, Nakatani Y, Evans RM 1997 Nuclear receptor coactivator ACTR is a novel histone acetyltransferase and forms a multimeric activation complex with $\mathrm{P} / \mathrm{CAF}$ and $\mathrm{CBP} /$ p300. Cell 90:569-580.

267. Baudino TA, Kraichely DM, Jefcoat SC Jr, MacDonald PN 1997 Isolation and characterization of NCoA-62, a novel coactivator protein involved in vitamin $\mathrm{D}$-mediated transcription. In: Norman AW, Bouillon R, Thomasset M (eds.) Vitamin D: Chemistry, Biology and Clinical Applications of the Steroid Hormone. University of California, Printing and Reprographics, Riverside, CA, U.S.A., pp. $320-321$.
268. Nakajima S, Yanagihara I, Ozono K 1997 A 65-kilodalton nuclear protein binds to the human vitamin D receptor: A bacterial-expressed histidine-tagged receptor study. Biochem Biophys Res Commun 232:806-809.

269. Le Douarin B, Zechel C, Garnier J-M, Lutz Y, Tora L, Pierrat B, Heery D, Gronemeyer H, Chambon P, Losson R 1995 The N-terminal part of TIF1, a putative mediator of the liganddependent activation function (AF-2) of nuclear receptors, is fused to B-raf in the oncogenic protein T18. EMBO J 14: 2020-2033.

270. May M, Mengus G, Lavigne A-C, Chambon P, Davidson I 1996 Human TAFII28 promotes transcriptional stimulation by activation function 2 of the retinoid X receptors. EMBO J 15:3093-3104.

271. Blanco JCG, Wang I-M, Tsai SY, Tsai M-J, O’Malley BW, Jurutka PW, Haussler MR, Ozato K 1995 Transcription factor TFIIB and the vitamin D receptor cooperatively activate ligand-dependent transcription. Proc Natl Acad Sci USA 92: $1535-1539$.

272. Masuyama H, Jefcoat SCJ, MacDonald PN 1997 The Nterminal domain of transcription factor IIB is required for direct interaction with the vitamin $\mathrm{D}$ receptor and participates in vitamin D-mediated transcription. Mol Endocrinol 11:218-228

273. Blanco JCG, Dey A, Leid M, Minucci S, Park B-K, Jurutka PW, Haussler MR, Ozato K 1996 Inhibition of ligand induced promoter occupancy in vivo by a dominant negative RXR. Genes Cells 1:209-221.

Address reprint requests to: Mark R. Haussler, Ph.D.

Department of Biochemistry College of Medicine The University of Arizona 1501 North Campbell Avenue Tucson, AZ 85724 U.S.A. 